\title{
Drug delivery systems for elemene, its main active ingredient $\beta$-elemene, and its derivatives in cancer therapy
}

This article was published in the following Dove Press journal:

International Journal of Nanomedicine

\author{
Bingtao Zhai' \\ Yiying Zeng ${ }^{2-5}$ \\ Zhaowu Zeng ${ }^{2-4}$ \\ Nana Zhang ${ }^{2-4}$ \\ Chenxi $\mathrm{Li}^{2-4}$ \\ Yijun Zeng ${ }^{2-4}$ \\ Yu You' \\ Shuling Wang ${ }^{2-4}$ \\ Xiabin Chen ${ }^{2-4}$ \\ Xinbing Sui ${ }^{2-4}$ \\ Tian $\mathrm{Xie}^{2-4}$ \\ 'College of Pharmacy, Chengdu \\ University of Traditional Chinese \\ Medicine, Chengdu, Sichuan, China; \\ ${ }^{2}$ Holistic Integrative Pharmacy \\ Institutes, Hangzhou Normal \\ University, Hangzhou, Zhejiang, \\ China; ${ }^{3}$ Key Laboratory of Elemene \\ Class Anti-cancer Chinese Medicine \\ of Zhejiang Province, Hangzhou, \\ Zhejiang, China; ${ }^{4}$ Engineering \\ Laboratory of Development and \\ Application of Traditional Chinese \\ Medicine from Zhejiang Province, \\ Hangzhou, Zhejiang, China; ${ }^{5} \mathrm{College}$ \\ of Pharmacy, Shanghai University \\ of Traditional Chinese Medicine, \\ Shanghai, China
}

\begin{abstract}
Class II antitumor drug extracted from the traditional Chinese medicine Curcuma wenyujin Y. H. Chen et C. Ling. $\beta$-elemene exerts its effects by inhibiting cell proliferation, arresting the cell cycle, inducing cell apoptosis, exerting antiangiogenesis and antimetastasis effects, reversing multiple-drug resistance (MDR), and enhancing the immune system. Elemene injection and oral emulsion have been used to treat various tumors, including cancer of the lung, liver, brain, breast, ovary, gastric, prostate, and other tissues, for $>20$ years. The safety of both elemene injection and oral emulsion in the clinic has been discussed. Recently, the secondary development of $\beta$-elemene has attracted the attention of researchers and made great progress. On the one hand, studies have been carried out on liposome-based systems (including solid lipid nanoparticles [SLNs], nanostructured lipid carriers [NLCs], long-circulating liposomes, active targeting liposomes, and multidrug-loaded liposomes) and emulsion systems (including microemulsions, self-emulsion drug delivery systems [SEDDSs], and active targeting microemulsion) to solve the issues of poor solubility in water, low bioavailability, and severe phlebitis, as well as to improve antitumor efficacy. The pharmacokinetics of different drug delivery systems of $\beta$-elemene are also summarized. On the other hand, a number of highly active anticancer $\beta$-elemene derivatives have been obtained through modification of the structure of $\beta$-elemene. This review focuses on the two drug delivery systems and derivatives of $\beta$-elemene for cancer therapy.
\end{abstract}

Keywords: $\beta$-elemene, pharmacokinetics, drug delivery system, derivative, safety

\section{Introduction}

Elemenes are a group of natural compounds extracted from the traditional Chinese medicinal plant Curcuma wenyujin Y. H. Chen et C. Ling (Figure 1). ${ }^{1}$ Elemene contains three unsaturated double bonds, which are classified into $\alpha$-elemene, $\beta$-elemene, and $\delta$-elemene according to the position of the double bond. Among them, $\beta$-elemene has the highest antitumor activity. ${ }^{2}$ The chemical name of $\beta$-elemene is 1 -methyl-1vinyl-2,4-diisopropenyl-cyclohexane (Figure 2), the molecular formula is $\mathrm{C}_{15} \mathrm{H}_{24}$, and the molecular weight of $\beta$-elemene is $204.35 \mathrm{~g} / \mathrm{mol}$. Compared to chemotherapeutic drugs, $\beta$-elemene is a noncytotoxic broad-spectrum antitumor drug. It not only inhibits tumor growth but also enhances the body's immune system. ${ }^{3}$ Chemotherapeutic drugs, such as 5-fluorouracil, temozolomide (TMZ), cisplatin, gefitinib, endostar, etoposide, rapamycin, oxaliplatin, taxanes, and ligustrazine, as well as radiotherapy and hyperthermia, could improve the antitumor effects and reverse multiple-drug resistance (MDR) in combination with $\beta$-elemene. ${ }^{4-20}$ In recent years, the study of mechanism of action of $\beta$-elemene has made great progress. $\beta$-elemene exerts its
Correspondence: Tian Xie; Zhaowu Zeng Holistic Integrative Pharmacy Institutes, Hangzhou Normal University,

1378 Wenyixi Road, Hangzhou,

Zhejiang $31 \mathrm{II} 2 \mathrm{I}$, China

Tel +8657l28868269

Email xbs@dljg.sina.net; artgreenking@।26.com 

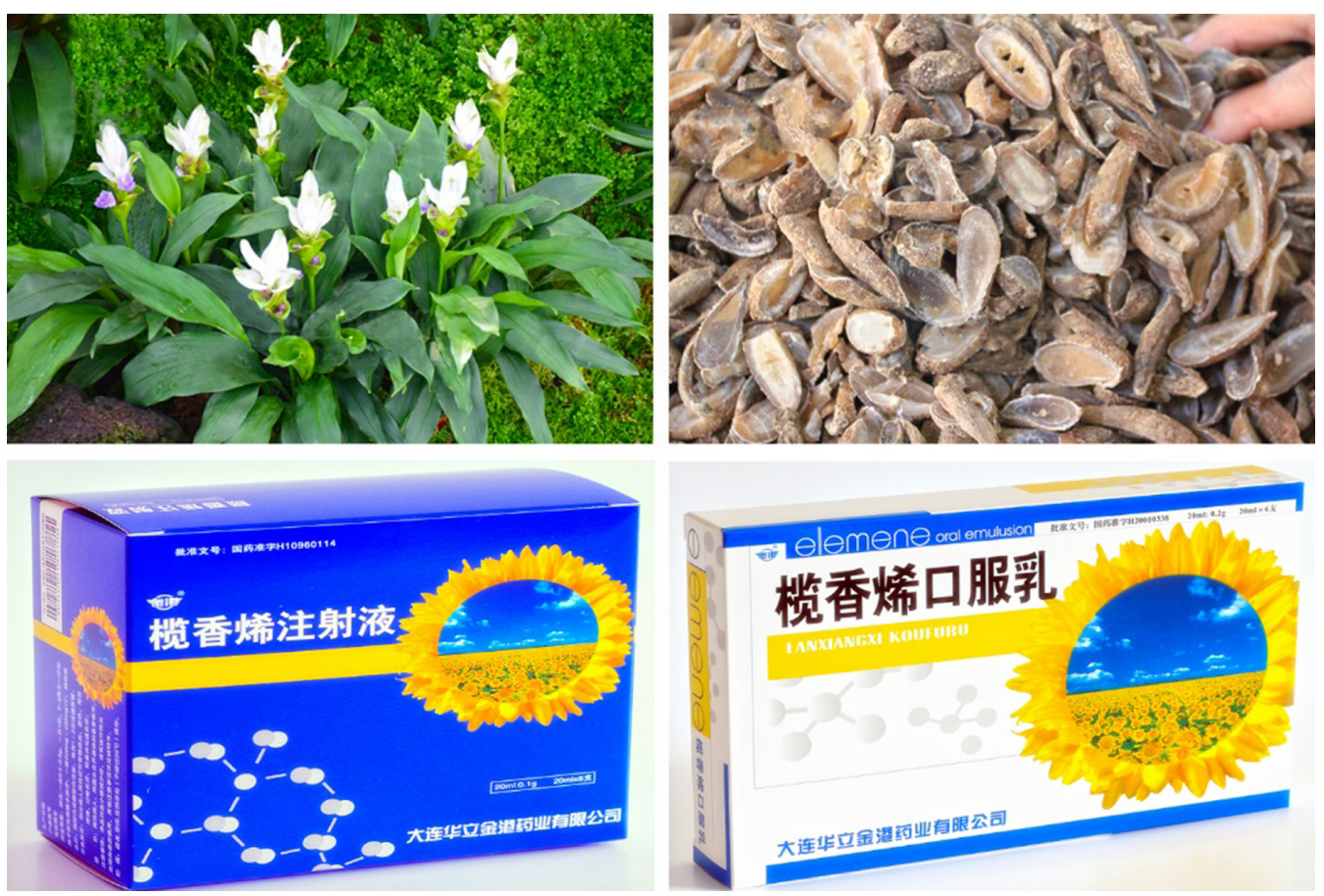

Figure I The source of elemene and its drug delivery systems approved by the CFDA. Abbreviation: CFDA, China Food and Drug Administration.

effects by modulating multiple molecular targets. It modulates CDKs to arrest the cell cycle and alters various proteins such as survivin, caspase, and the Bcl-2 family proteins to induce cell apoptosis. In addition, $\beta$-elemene targets the Wnt/ $\beta$-catenin, Notch, PI3K/Akt/mTOR, and MAPK/ERK signaling pathways and regulates transcription factors such as STAT3. Furthermore, $\beta$-elemene regulates several key molecules of tumor angiogenesis and metastasis, such as VEGF and matrix metalloproteinase, in addition to modulating the expression of ncRNAs that contribute to anticancer activities. $^{21-34}$

However, the clinical application of elemene has been limited by its poor solubility in water, poor stability, and low bioavailability. Therefore, studying a new drug delivery system for elemene has important significance. Currently, elemene liposome injection and oral emulsion have been approved by the China Food and Drug Administration (CFDA) to treat various cancers, and these have achieved a synergistic effect with chemotherapy in the clinic (Figure 1). ${ }^{35}$ Chemotherapy combined with elemene injection significantly improved survival and tumor response, as well as reduced toxicity. ${ }^{36-38}$ However, elemene injection could cause severe phlebitis and other side effects after intravenous (iv) injection. The safety of elemene injection and oral emulsion in the clinic is summarized. Currently, novel delivery systems, including solid lipid nanoparticles (SLNs), nanostructured lipid carriers (NLCs), long-circulating liposomes, active targeting SLNs, multidrug-loaded liposomes and microemulsions, selfemulsion drug delivery systems (SEDDSs), and active targeting microemulsions, have been actively developed and these have contributed to many advancements for elemene. The pharmacokinetics of different drug delivery systems is also discussed.

$\beta$-elemene has moderate antitumor activity and is mainly used as an adjunctive drug to enhance the efficacy, reduce the toxicity of chemoradiotherapy, and reverse drug resistance. Because of the moderate anticancer activity and poor solubility in water, researchers have synthesized a variety of $\beta$-elemene derivatives and studied their antitumor activities. The structure of $\beta$-elemene does not contain any active groups other than the double bond. The derivatization of $\beta$-elemene mainly introduces nitrogen, oxygen, sulfur groups, or radioactive elements. Thus far, many kinds of $\beta$-elemene derivatives have been reported, including amines, esters, alcohols, amino acids, aldehydes, and radioactive conjugates. ${ }^{39}$ The following section will also discuss the derivatives with antitumor activity and the preliminary relationship between the structure and antitumor activity.

\section{Pharmacokinetics}

Pharmacokinetics consists of studying the absorption, distribution, metabolism, and excretion of drugs in order to understand their toxicological and pharmacological impacts on the body. Understanding drug pharmacokinetic behaviors helps 


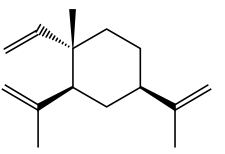

$\beta$-elemene<smiles>C=C[C@]1(C)CC[C@@H]([C@@](C)(O)CO)C[C@@H]1C(=C)C</smiles>

Lr-1<smiles>C=C[C@]1(C)CC[C@@H](C(=C)COC(=O)CCC(=O)OCCOc2no[n+]([O-])c2S(=O)(=O)c2ccccc2)C[C@@H]1C(=C)C</smiles>

11a<smiles>C=C[C@]1(C)CC[C@@H](C(=C)COCC(O)CN2CCN(CC(O)COCC(=C)[C@@H]3CC[C@@](C)(C=C)[C@H](C(=C)C)C3)CC2)C[C@H]1C(=C)C</smiles>

$6 q$

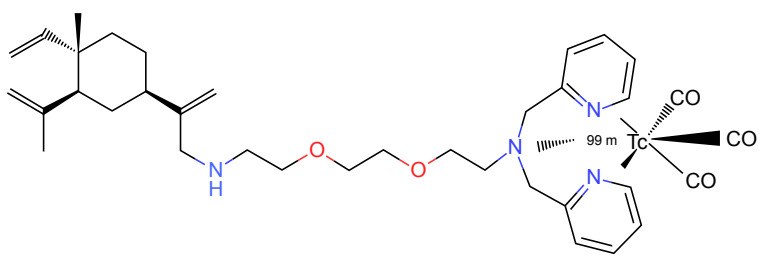

Radioactive conjugate 9

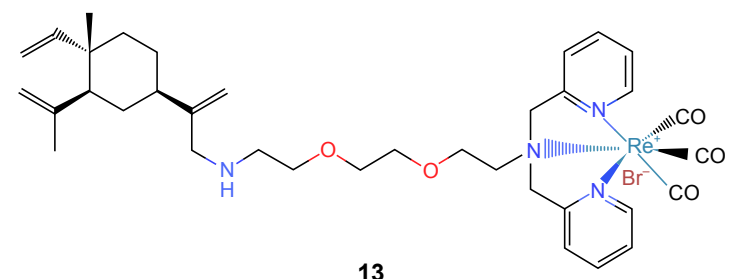<smiles>C=C[C@]1(C)CCC(C(=C)CN2CCNC(C)C2)C[C@@H]1C(=C)C</smiles>

DX1

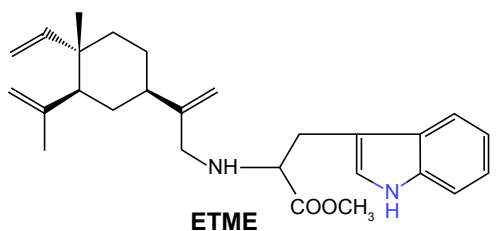

ETME<smiles>C=C[C@]1(C)CCC(C(=C)CN2CC(C)N[C@H](C)C2)C[C@H]1C(=C)CN1CC(C)NC(C)C1</smiles>

Ili

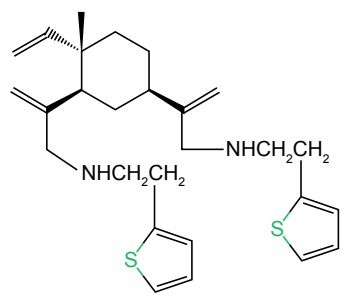

IIm

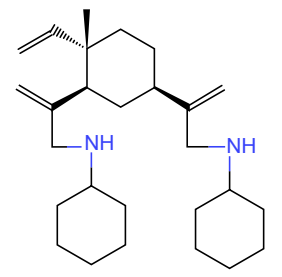

IIn

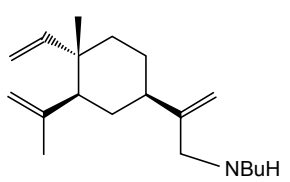

$4 a$

Figure 2 The structure of $\beta$-elemene and its derivatives.

Notes: 4a, monosubstituted amine derivative of $\beta$-elemene; 6q, $\beta$-elemene isopropanolamine; I la, furoxan-based NO-donating $\beta$-elemene hybrid; I3, Re(CO) - - $\beta$-elemene derivative; Ili, I3,I4-bis(cis-3,5-dimethyl-I-piperazinyl)- $\beta$-elemene; IIm, I3, I4-bis[2-(2-thiophenyl)ethylamino]- $\beta$-elemene; IIn, I3, I4-bis(cyclohexamino)- $\beta$-elemene; DXI, I3-(3-methyl-I-piperazinyl)-3-elemene; Lr-I, [(R or S)-2-((IR,3S,4S)-3-isopropenyl-4-methyl-4-vinyl-cyclohexyl)-propane-I,2-diol; Lr-2, (S)-2-((IR,3S,4S)-3-isopropenyl-4methyl-4-vinyl-cyclohexyl)-propane-I,2-diol and (R)-2-((IR,3S,4S)-3-isopropenyl-4-methyl-4-vinyl-cyclohexyl)-propane-I,2-diol.

Abbreviation: ETME, $N$ - $(\beta$-elemene-|3-y|)tryptophan methyl ester.

to establish the appropriate dose and avoid adverse effects..$^{40}$ $\beta$-elemene can be administered by the iv route to reach the target organs through blood circulation, and its concentration in plasma can be measured by gas chromatography.
It is important to study the relationship between $\beta$-elemene and drug-carrying protein. Wang et $\mathrm{al}^{41}$ had indicated that $\beta$-elemene bound extensively to rat plasma protein with binding values of $97.7 \% \pm 0.7 \%$ and $96.5 \% \pm 0.4 \%$ at 
$0.06 \mathrm{mg} / \mathrm{mL}$ and $0.1 \mathrm{mg} / \mathrm{mL}$, respectively. Zhang et $\mathrm{al}^{42}$ had revealed that electrostatic attraction played a role in the binding of $\beta$-elemene to human serum albumin. $\beta$-elemene showed a linear pharmacokinetics after iv injection into rats, with a terminal half-life $\left(T_{1 / 2}\right)$ of approximately 1 hour. It also had a large volume of distribution at steady state ( $V$ dss) of $1.9-2.6 \mathrm{~L} / \mathrm{kg}$. After administration to rats, the drug was distributed to heart, liver, spleen, lung, kidney, brain, gastrointestinal tract, fat, muscle, and testis, and maximum levels were observed at 15 minutes. The heart exhibited the highest concentration, while the plasma and testis showed the lowest concentration. Because of the great lipophilicity, $\beta$-elemene could cross the blood-brain barrier and had a high affinity for fat depots even after 3 hours. Less than $2 \%$ of the drug was recovered in bile, urine, or feces, indicating that the drug was excreted rapidly and metabolized extensively before elimination. ${ }^{41}$ Chen et $\mathrm{al}^{43}$ had developed a sensitive gas chromatography-mass spectrometry method to conduct a clinical trial to evaluate $\beta$-elemene emulsion injection in patients with lung cancer and brain metastases. The maximum plasma concentration $\left(C_{\max }\right)$ and the area under the curve (AUC) showed linear pharmacokinetic properties. The plasma concentration decreased rapidly, with a $T_{1 / 2}$ between 1.91 and 2.41 hours and the time to maximum plasma concentration $\left(T_{\max }\right)$ of 3 hours. Although some evidence indicated that the metabolite $\beta$-elemenal was present in rat bile, it was not a metabolite in human plasma and urine. ${ }^{43}$ In summary, $\beta$-elemene is widely distributed in the body after iv injection and is able to pass the blood-brain barrier, but it has a short half-life. It is necessary to prolong the halflife to reduce the frequency of dosing. The pharmacokinetic parameters of $\beta$-elemene and its formulations in rats are summarized in Table 1.

\section{Drug delivery systems}

Elemene suffers from poor solubility in water, poor stability, and low bioavailability. ${ }^{51}$ Liposomes have attracted much interest for several years in terms of biocompatibility, delivery, and target potential. Liposomes are spherical vesicles created by a lipid bilayer of phospholipids. Based on the theory of "molecular compatibility", Xie et al ${ }^{52}$ adopted a green falling film molecular distillation refining technology to extract and separate elemene from C. wenyujin Y. H. Chen et C. Ling., followed by liposome-targeted technology to encapsulate elemene in the phospholipid bilayer. This technology became China's first Good Manufacturing Practice (GMP)-certified liposome industrialization production line. In 1994, elemene liposome injection and oral emulsion were successfully launched and became a national Class II anticancer drug with Chinese intellectual property rights. ${ }^{52}$ Elemene liposome is a noncytotoxic antitumor drug with a high content of anticancer active ingredients ( $85 \% \beta$-elemene), and it is also called "green therapy" for the treatment of cancer. In the clinic, elemene liposomes can be used as a single drug, be combined with chemoradiotherapy, or be used during the perioperative period. Twenty years of clinical studies have shown that elemene liposomes can inhibit multiple cancer cells through multiple targets and can improve immune function. In particular, it has obvious advantages in improving the patient's quality of life, prolonging the survival period, resisting metastasis and recurrence, and reversing MDR. At present, Jingang Elemene Injection and Oral Emulsion have entered the "National Medical Insurance Drug List" and have been used in $>3,000$ hospitals in China, benefitting $>0.7$ million cancer patients, including those in Southeast Asia, Hong Kong, Japan, Korea, Europe, and America. Part of the instructions of elemene injection and oral emulsion approved by the CFDA are shown in Table 2.

Currently, novel delivery systems are active and provide advancements for elemene liposomes, including liposomal nanoparticles, long-circulating liposomes, thermosensitive long-circulating liposomes, active targeting liposomes, and multidrug-loaded liposomes.

\section{Liposomal nanoparticles}

SLNs and NLCs are two types of lipid nanoparticles that have been used in the biomedical field for $>25$ years. SLNs were developed first and are composed only of solid lipids, which overcame the limitations of liposomes such as toxicity, stability, and low loading capacities. ${ }^{53}$ Wang et al ${ }^{44}$ successfully developed $\beta$-elemene SLNs by combining the techniques of probe sonication and membrane extrusion. SLNs were stable for at least 8 months, with size of $48.9 \pm 2.6 \mathrm{~nm}$, zeta potential of $-30.7 \pm 4.5 \mathrm{mV}$, concentration of $5.6 \pm 0.2 \mathrm{mg} / \mathrm{mL}$, and entrapment efficiency of $99.7 \% \pm 2.5 \%$. In vitro release of $\beta$-elemene from the SLNs was slow and stable and was found to follow the Higuchi equation. Following iv administration, the concentrations of $\beta$-elemene in SLNs were 1.5, 2.9, and 1.4 times higher in the liver, spleen, and kidney than those of the $\beta$-elemene emulsion. $\beta$-elemene-loaded SLNs showed a high uptake by the reticuloendothelial system (RES), which might be a potential drug for hepatic carcinoma. ${ }^{44,45}$ NLCs are an upgrade of the SLNs and are composed of a mixture of solid and liquid lipids. This next generation of SLNs not only presented improved loading efficiencies and stability but also prevented the tendency 


\begin{tabular}{|c|c|c|c|c|c|c|c|c|c|c|c|c|c|c|c|}
\hline$\underline{\mathscr{\Phi}}$ & テテすすをと ケ & \& & fo & f & $\hat{f}$ & $\hat{f}$ & f & $\stackrel{\infty}{+}$ & $\stackrel{\infty}{+}$ & $\dot{q}$ & g & 음 & 오 & in & 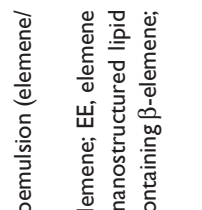 \\
\hline 寅 & 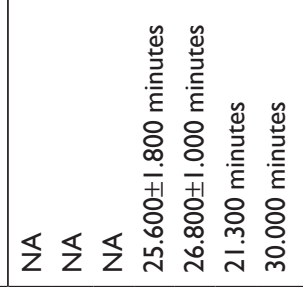 & 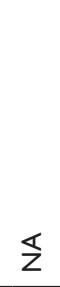 & $\S$ & 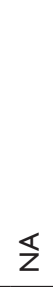 & $\S$ & $\S$ & $\S$ & 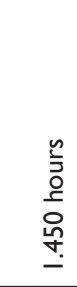 & 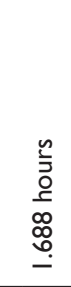 & $\S$ & $\S$ & 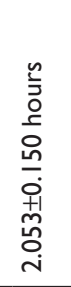 & 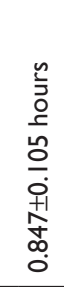 & 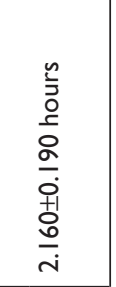 & 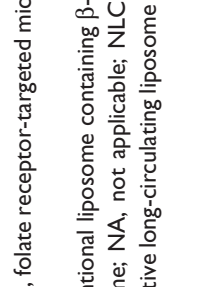 \\
\hline U & 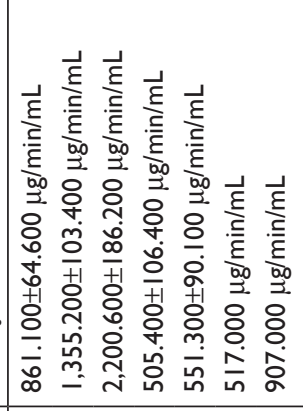 & 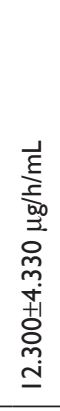 & 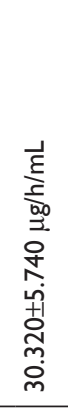 & 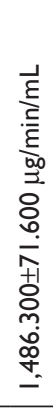 & 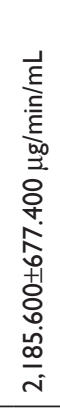 & 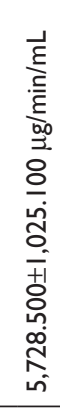 & 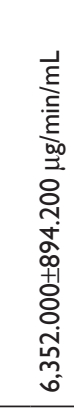 & 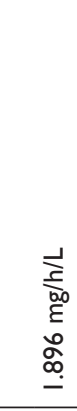 & 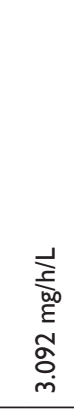 & 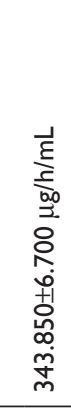 & 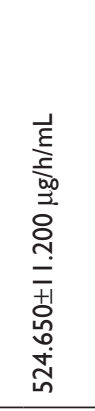 & 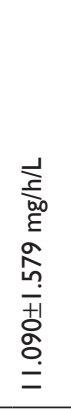 & 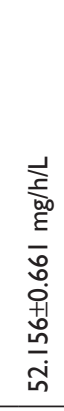 & 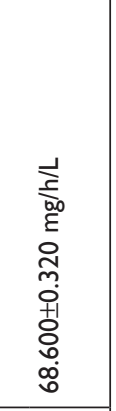 & 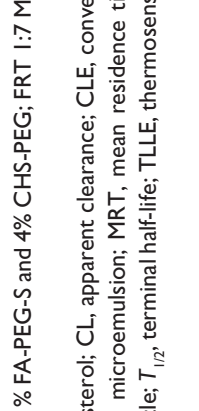 \\
\hline $\bar{u}$ & 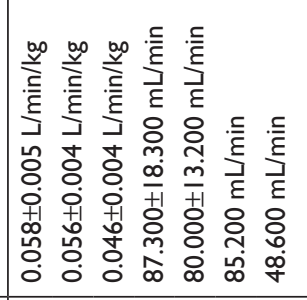 & 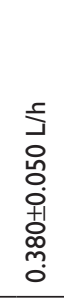 & $\begin{array}{l}5 \\
5 \\
0 \\
0 \\
0 \\
\text { 11 } \\
0 \\
0 \\
\end{array}$ & $\S$ & 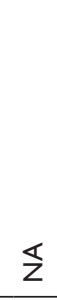 & $\S$ & $\S$ & 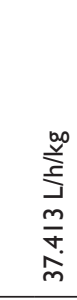 & 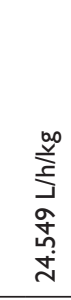 & $\S$ & $\S$ & 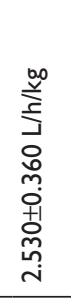 & 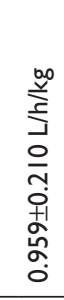 & 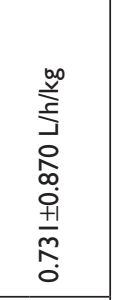 & 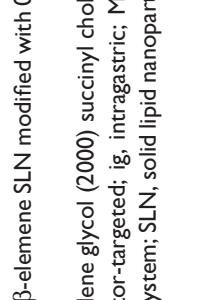 \\
\hline$>$ & 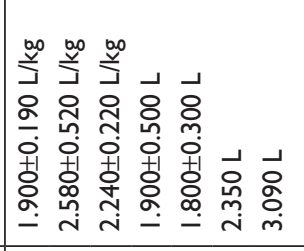 & 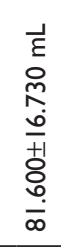 & 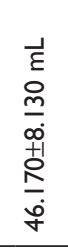 & $\S$ & $\overleftarrow{z}$ & $\Sigma$ & $\S$ & z & $\S$ & $\S$ & $\S$ & 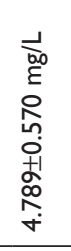 & 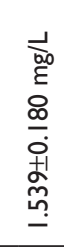 & 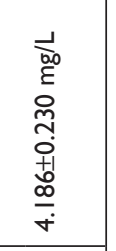 & $\begin{array}{l}\hat{\lambda} \\
\overline{0} \\
\bar{\lambda} \\
\bar{\lambda} \\
\overline{0} \\
\overline{0} \\
\overline{0} \\
0 \\
0 \\
0\end{array}$ \\
\hline $\mathrm{r}^{-}$ & 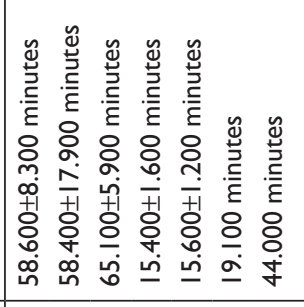 & 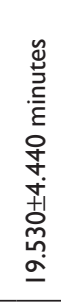 & 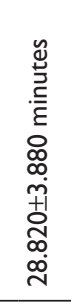 & 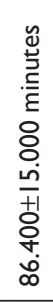 & 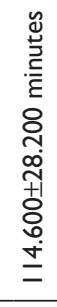 & 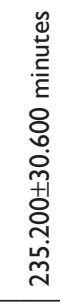 & 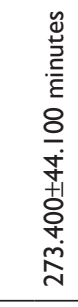 & 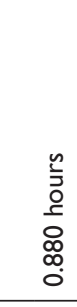 & 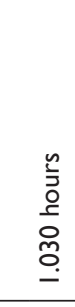 & 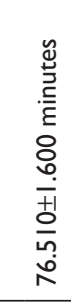 & 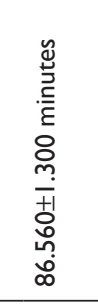 & 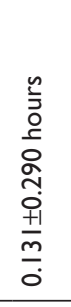 & 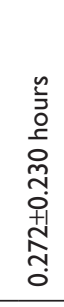 & 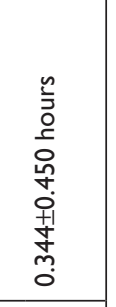 & 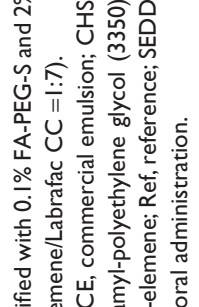 \\
\hline & 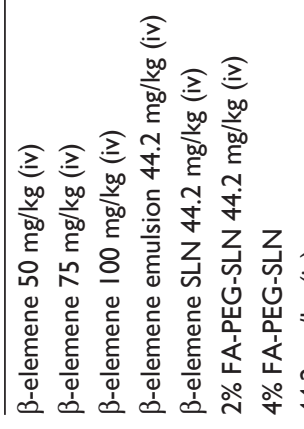 & & & & & & 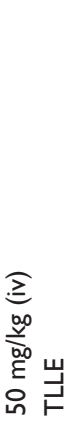 & $\stackrel{\text { 哭 }}{\mathrm{u}}$ & 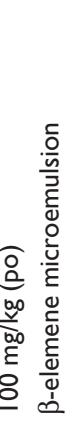 & $\begin{array}{l}\varepsilon \\
\bar{v} \\
\bar{v} \\
\underline{\tilde{g}}\end{array}$ & 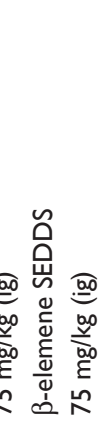 & & 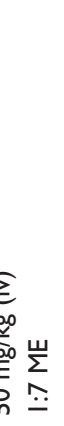 & 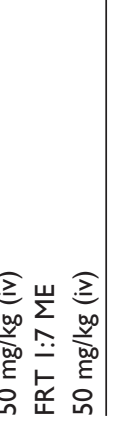 & \\
\hline
\end{tabular}


Table 2 Partial instructions of elemene injection and oral emulsion approved by the CFDA

\begin{tabular}{|c|c|c|}
\hline Instructions & Elemene injection (liposome) & Elemene oral emulsion \\
\hline $\begin{array}{l}\text { Medical } \\
\text { supplement }\end{array}$ & $\begin{array}{l}\text { Soybean phospholipid, cholesterol, ethanol, dibasic sodium phosphate, } \\
\text { sodium dihydrogen phosphate }\end{array}$ & NA \\
\hline Indications & $\begin{array}{l}\text { This product, combined with radiotherapy and chemotherapy, can } \\
\text { enhance the efficacy against lung cancer, liver cancer, esophageal } \\
\text { cancer, nasopharyngeal carcinoma, brain tumor, bone metastasis, } \\
\text { and other malignant tumors, as well as reduce the side effects of } \\
\text { radiotherapy and chemotherapy. It can also be used for interventional, } \\
\text { intracavitary chemotherapy and treatment of cancerous ascites }\end{array}$ & $\begin{array}{l}\text { This product is used for adjuvant treatment of } \\
\text { esophageal cancer and gastric cancer to improve } \\
\text { symptoms }\end{array}$ \\
\hline Specification & $20 \mathrm{~mL}: 0.1 \mathrm{~g}$ & $20 \mathrm{~mL}: 0.2 \mathrm{~g}$ \\
\hline $\begin{array}{l}\text { Dosage and } \\
\text { administration }\end{array}$ & $\begin{array}{l}\text { Intravenous injection: once } 0.4-0.6 \mathrm{~g} \text {, once a day, } 2-3 \text { weeks for a } \\
\text { course of treatment } \\
\text { For the treatment of malignant hydrothorax and ascites: generally, } \\
200-400 \mathrm{mg} / \mathrm{m}^{2} \text {, after pumping ascites, intrathoracic or intraperitoneal } \\
\text { injection, one or two times a week or as directed }\end{array}$ & $\begin{array}{l}\text { Oral, } 20 \mathrm{~mL} \text { once, three times a day. Swallowing } \\
\text { on an empty stomach before meals, taking } \\
4-8 \text { weeks for a course of treatment or as } \\
\text { directed }\end{array}$ \\
\hline $\begin{array}{l}\text { Adverse } \\
\text { reactions }\end{array}$ & $\begin{array}{l}\text { Some patients may have phlebitis, fever, local pain, allergic reaction, } \\
\text { mild digestive tract reaction after medication }\end{array}$ & $\begin{array}{l}\text { Some patients may have digestive tract } \\
\text { reactions, such as nausea, vomiting, and diarrhea, } \\
\text { occasional loss of appetite, hemoglobin decline, } \\
\text { and leukopenia. Most of the adverse reactions } \\
\text { were mild and did not affect treatment }\end{array}$ \\
\hline
\end{tabular}

Abbreviations: CFDA, China Food and Drug Administration; NA, not applicable.

to expel gel and drug during storage. ${ }^{54}$ Shi et $\mathrm{al}^{46}$ prepared $\beta$-elemene-loaded NLCs by the hot-melting high-pressure homogenization method using glycerol monostearate as the solid lipid, a mixture of Maisine 35-1 and Labrafil M1944 CS (1:1; Gattefosse, Saint Priest, France) as the liquid lipid, and a mixture of Tween 80 and soybean lecithin (1:1) as the surfactants. The optimal formulation contained $6 \%$ lipids and $5 \%$ surfactants, and the $\mathrm{S} / \mathrm{L}$ ratio (weight ratio of the solid lipid to liquid lipid) and $\mathrm{D} / \mathrm{L}$ ratio (the weight ratio of the drug to the total lipids) were $2: 3$ and $1: 10$, respectively. $\beta$-elemene NLC was spheroidal, with a mean size of $139.8 \mathrm{~nm}$, polydispersity index of 0.085 , zeta potential of $-20.2 \mathrm{mV}$, drug loading of $8.45 \% \pm 0.57 \%$, and entrapment efficiency of $82.11 \% \pm 1.84 \%$. $\beta$-elemene NLC also showed a 1.5-, 1.8-, and 3.5-fold-lower elimination rate constant $(K e), V \mathrm{dss}$, and apparent clearance (CL) and a 2.5-fold-higher AUC compared to the elemene injection. Furthermore, the antitumor efficacy of $\beta$-elemene NLC was enhanced, which might be attributed to the increased bioavailability. $\beta$-elemene NLC also reduced venous irritation. ${ }^{46}$

\section{Long-circulating liposomes}

Although liposomal nanoparticles increase the bioavailability of $\beta$-elemene, they are easily cleared by the kidneys and taken up by the RES residing in the liver and the spleen because of the small particle size. A commonly used strategy to avoid the RES is to graft the particle surface with polyethylene glycol (PEG), which shields from interaction with macrophages and creates a long circulating "stealth" effect. The long circulation time and improved stability allow for them to extravasate to the tumor site and be retained for days. ${ }^{55} \mathrm{Qi}^{56}$ prepared a $\beta$-elemene sterical-stabilized liposome using an ethyl ether injection method containing $100 \mathrm{mg}$ of phospholipid, $10 \mathrm{mg}$ of cholesterol, $10 \mathrm{mg}$ of distearoyl phosphatidyl ethanolamine-poly(ethylene glycol) 2000 (DSPE-PEG2000) and $50 \mathrm{mg}$ of $\beta$-elemene, with size of $110 \mathrm{~nm}$, $\mathrm{pH}$ of $6.4-6.7$, content of $10 \mathrm{mg} / \mathrm{mL}$, and average entrapment efficiency of $97 \%$. Pharmacokinetics showed that sterically stabilized liposomes of $\beta$-elemene could prolong the residence time of $\beta$-elemene in blood and exhibit long cycle characteristics. ${ }^{56}$ $\mathrm{Li}^{57}$ prepared a $\beta$-elemene long-circulating liposome using the ethanol injection method with the ratio of phospholipid to cholesterol of $5: 1$, containing $50 \mathrm{mg}$ of $\beta$-elemene and $0.05 \%$ PEG2000. The average size was $221.4 \mathrm{~nm}$, and the average entrapment efficiency was $92.7 \%$. The longcirculating liposome showed 6.0- and 1.6-times-higher $T_{1 / 2}$ and AUC and 0.5-times-lower CL compared to $\beta$-elemene liposome. ${ }^{57}$ Wang $^{47}$ developed a PEGylated liposome containing $\beta$-elemene (PLE) using ethanol injection method with size of $149 \mathrm{~nm}$ and entrapment efficiency of $95.2 \%$. The optimized prescription ratio of phospholipid, cholesterol, and DSPE-PEG2000 was 3:1:0.2, and the concentration of $\beta$-elemene was $5 \mathrm{mg} / \mathrm{mL}$. A thermosensitive long-circulating liposome containing $\beta$-elemene (TLLE) was also prepared using the film dispersion method with the size of $103 \mathrm{~nm}$ and entrapment efficiency of $87.9 \%$. The optimized prescription ratio of dipalmitoyl phosphatidyl choline (DPPC), distearoyl phosphatidyl choline (DSPC), and DSPE-PEG2000 was 
9:1:0.6. The PLE showed a 2.7-, 3.9-, and 2.3-fold-higher $T_{1 / 2}$, $\mathrm{AUC}_{(0-t)}$, and $\mathrm{MRT}_{(0-t)}$, and the TLLE showed a 3.2-, 4.2-, and 2.3-fold-higher $T_{1 / 2}, \mathrm{AUC}_{(0-t)}$, and $\mathrm{MRT}_{(0-t)}$ than elemene emulsion (EE). The in vivo circulation time of $\beta$-elemene in TLLE and PLE was significantly prolonged, and the bioavailability of TLLE and PLE was significantly improved. TLLE and PLE could decrease uptake by liver and spleen and target the drug to the tumor. In particular, TLLE had thermosensitive property, and its ability to target to tumors rapidly increased with heat treatment (HT). The tumor inhibition rate of TLLE combined with HT reached 69\%. PLE had a high inhibition rate $(56 \%)$ at normal animal heat. ${ }^{47}$

\section{Active targeting liposome}

Despite the general trend of improved circulation time of PEGylated liposomes, researchers have found that some PEGylated liposomes do not release the drug on arrival at the tumor site..$^{55}$ They also observed an increased clearance rate of PEGylated nanoparticles from the blood with the increase in the number of injections administered, which was called the accelerated blood clearance (ABC) phenomenon. To increase the accumulation of antitumor drugs at the tumor site while improving the circulation time, active targeting using liposomes is achieved via conjugation of one or more ligands to the liposome surface to form liposomes that bind to a target receptor expressed on the tumor cell surface. ${ }^{58}$ $\mathrm{Wang}^{45}$ prepared a folate receptor-targeted (FRT) SLN for $\beta$-elemene (FA-PEG-SLN) containing $350 \mathrm{mg}$ of Precirol ATO, $150 \mathrm{mg}$ of glyceryl monostearate, $250 \mathrm{mg}$ of Lutrol F68, 0.1\% [ $N$-stearyl- $N$-pteroylglutamyl-polyethylene glycol (3350) bis-amine] (FA-PEG-S), 4\% [monomethoxy polyethylene glycol (2000) succinyl cholesterol] (CHS-PEG), 10 $\mathrm{mL}$ of distilled water, and $5.6 \mathrm{mg} / \mathrm{mL} \beta$-elemene, with size of $42.2 \pm 2.1 \mathrm{~nm}$, zeta potential of $-12.60 \pm 1.3 \mathrm{mV}$, and average entrapment efficiency of $97.5 \% \pm 1.7 \%$. The $T_{1 / 2}$ of FA-PEGSLN was 44.0 minutes, which was longer than that of the emulsion (15.4 minutes). The cancer growth inhibition rates of FA-PEG-SLN, PEG-SLN ( $\beta$-elemene SLN modified with $4 \%$ CHS-PEG), and SLN-1 (conventional SLN containing $\beta$-elemene) were $49.5 \%, 48.87 \%$, and $47.78 \%$, respectively, which were markedly higher than that of the control emulsion with inhibition rate of $18.68 \%$. However, the inhibition rate of FA-PEG-SLN was not obviously improved compared to that of PEG-SLN and SLN-1. ${ }^{45}$

\section{Multidrug-loaded liposomes}

It is generally acknowledged that combination therapy has long been adopted as the standard first-line treatment to improve the clinical outcome in cancer therapy. However, the clinical results are often limited by higher toxicity and inability of component drugs to achieve desired spatiotemporal distribution. The success of combination therapy is also hampered by the varying pharmacokinetics of the drugs, thereby causing the uncoordinated uptake of various drugs by the tumor cell and reducing their synergistic effects. Recently, the strategy to coencapsulate and co-deliver multiple therapeutic agents using the liposome has been undertaken by an increasing number of researchers. ${ }^{59-61}$ Dong $^{62}$ developed dual-drug liposomes containing $20 \mathrm{mg}$ of curcumin, $5 \mathrm{mg}$ of $\beta$-elemene, $666.7 \mathrm{mg}$ of lecithin, and $133.3 \mathrm{mg}$ of cholesterol, with size of $232.0 \pm 6.4 \mathrm{~nm}$ and potential of $0.71 \pm 0.1 \mathrm{mV}$. The encapsulation efficiency of $\beta$-elemene was $97.86 \% \pm 1.53 \%$, and the entrapment efficiency of curcumin was $97.71 \% \pm 1.53 \%$. The dual-drug liposomes inhibited the growth of LLC cells, and the inhibition rate was significantly higher than that of a solution with high concentration of docetaxel. However, the total drug loading was only $0.1925 \% \pm 0.006 \%$, and the liposome was delivered by atomizing inhalation. ${ }^{62}$

Emulsion technology has been widely used in the pharmaceutical industry. Emulsions are metastable colloidal systems composed of two immiscible liquids (water and oil) to form a single phase stabilized by an interfacial film of emulsifiers or surfactants. ${ }^{63}$ Elemene oral emulsion has been approved as an adjunctive treatment for gastric cancer and esophageal cancer. The novel delivery systems also include advancements in EE, including microemulsion, SEDDS, and active targeting microemulsion.

\section{Microemulsion}

Microemulsions are transparent, optically isotropic, and thermodynamically stable phase-transition systems that possess improved appearance, high stability, easiness of preparation, low surface tension, and diameter of $10-100 \mathrm{~nm} .{ }^{64}$ Zeng et $\mathrm{al}^{48}$ developed an elemene oil-in-water $(\mathrm{O} / \mathrm{W})$ microemulsion containing $1 \%$ elemene as the oil phase and drug, $5 \%$ polysorbate 80 and $5 \%$ ethanol as the surfactant, $15 \%$ propylene glycol as the cosurfactant, and $15 \%$ glycerol as the tackifier and absorption enhancer, with size of $57.7 \pm 2.8 \mathrm{~nm}$, polydispersity index of $0.485 \pm 0.032$, zeta potential of $3.2 \pm 0.4 \mathrm{mV}, \mathrm{pH}$ of $5.19 \pm 0.08$, viscosity of $6 \mathrm{mPa} \cdot \mathrm{s}$, surface tension of $31.8 \pm 0.3 \mathrm{mN} / \mathrm{m}$, content of $8.273 \pm 0.018 \mathrm{mg} / \mathrm{mL}$, and average entrapment efficiency of $99.81 \% \pm 0.24 \%$. The $C_{\max }$ of the microemulsion was 1.3 times that of the emulsion. The bioavailability of the microemulsion was $163.1 \%$ compared with that of the commercial emulsion. ${ }^{48}$ $\mathrm{Hu}$ et $\mathrm{al}^{65}$ prepared $\beta$-elemene-loaded microemulsion using a simple water titration method involving $1 \%$ elemene, 
7\% Labrafac CC, 8\% phosphatidylcholine, 8\% HS-15, $16 \%$ propylene glycol, and 60\% PBS solution ( $\mathrm{pH} 7.4$ ) containing $0.5 \% \mathrm{NaHSO}_{3}$, with $\mathrm{pH}$ of $7.32 \pm 0.01$, osmotic pressure of $279 \pm 3 \mathrm{mosm} / \mathrm{kg}$, viscosity of $(5.56 \pm 0.11) \times 10^{-3}$, conductivity of $1.14 \times 10^{-2} \pm 7.9 \times 10^{-5} \mathrm{~s} / \mathrm{m}$, refractive index of $1.458 \pm 0.004$, zeta potential of $-2.64 \pm 0.06 \mathrm{mV}$, and mean size of $38.3 \pm 4.3 \mathrm{~nm}$. The microemulsion could steadily release the drug for 12 hours. ${ }^{65}$

\section{SEDDS in treatment}

SEDDS have been widely used to improve the oral bioavailability of poorly soluble drugs. They comprise isotropic mixtures of oils with surfactants and cosurfactants that undergo self-emulsification to form $\mathrm{O} / \mathrm{W}$ nano- or microemulsions when they are exposed to gastrointestinal fluids under mild agitation provided by the gastrointestinal tract's peristaltic movements. ${ }^{66}$ Chen $^{67}$ prepared a $\beta$-elemene SEDDS soft capsule. The optimized prescription ratio of $\beta$-elemene, ethyl oleate, Tween 85, and Transcutol was 55:45:60:40 (mass value) on the pseudoternary phase diagrams. The particle size was approximately $320 \mathrm{~nm}$, and the zeta potential was approximately $-3 \mathrm{mV}$. Compared with conventional emulsion of $\beta$-elemene, the bioavailability of SEDDS soft capsules was $120.68 \%$. The absorption degrees of SEDDS soft capsules of $\beta$-elemene and conventional emulsion were equal. ${ }^{67} \mathrm{Li}^{49}$ prepared a solid self-microemulsion drug delivery system (S-SMEDDS) for $\beta$-elemene. The optimized prescription ratio of $\beta$-elemene, Cremophor EL 35 (EL-35), Labrasol (LAS), and total saponins of honey locust was $3: 2: 2: 3$. The particle size was approximately $158 \mathrm{~nm}$. The relative bioavailability of S-SMEDDS was $152.6 \%$, and it had a greatly improved $C_{\text {max }}$ of $6.946 \pm 0.33 \mu \mathrm{g} / \mathrm{mL}, T_{\max }$ of $86.56 \pm 1.3$ minutes, and AUC of $524.65 \pm 11.2 \mu \mathrm{g} / \mathrm{h} / \mathrm{mL}$ compared with the market emulsion of $\beta$-elemene. The total saponins of honey locust were used as emulsifier for the first time to reduce emulsifier toxicity and enhance efficacy, but the effect was not good. ${ }^{49}$

\section{Active targeting microemulsion}

FRT microemulsion is also used to enhance the antitumor effects of $\beta$-elemene. $\mathrm{Hu}^{50}$ prepared a folate receptormediated $\beta$-elemene microemulsion with $1 \%$ elemene, $7 \%$ Labrafac CC, 8\% phosphatidylcholine, 1,2-oil acyl phosphatidylethanolamine-polyethylene glycol-folic acid (FAPEG2000-DOPE) and phospholipid in molar ratio of 1\%-2\%, $8 \%$ polyoxyethylene esters of PEG-(660)-12-hydroxyl (HS-15), 16\% propylene glycol, and 58\%-59\% PBS buffer solution ( $\mathrm{pH} 7.4$ ) containing $0.5 \% \mathrm{NaHSO}_{3}$. The diameter of folate receptor-mediated $\beta$-elemene microemulsion was
$42.5 \pm 6.3 \mathrm{~nm}$. The $T_{1 / 2}$ and $\mathrm{AUC}_{0-\infty}$ of the FA-PEG-DOPEmodified FRT 1:7 microemulsion (ME) (elemene/Labrafac $\mathrm{CC}=1: 7$ ) were $0.344 \pm 0.45$ hours and $68.60 \pm 0.32 \mathrm{mg} / \mathrm{h} / \mathrm{L}$, respectively, which were 2.6 and 6.2 fold greater than those of the commercial emulsion. FRT 1:7 ME also increased the amount of $\beta$-elemene in the tumor. ${ }^{50}$

Currently, there are many studies on elemene liposome drug delivery systems. Liposomes can be prepared by various methods, such as hot-melting high-pressure homogenization method, ether injection method, ethanol injection method, and film dispersion method. Research on the EE drug delivery system has mainly focused on microemulsion and SMEDDS, and the preparation methods are few. The elemene liposome is PEGylated to form elemene long-circulating liposomes, which can further improve the bioavailability of elemene, reduce the number of administrations, and increase the antitumor effect. At present, the research and development technology of elemene long-circulating liposomes is increasingly mature; thus, industrial development of the same can be considered. Elemene liposomes are mainly administered by iv injection, and EEs are mainly absorbed orally; therefore, the bioavailability is low, and the dosage needs to be increased. After the elemene oral emulsion is improved into microemulsion and self-microemulsion, the bioavailability is further improved, and the direct contact with the tumor site after oral administration further increases the antitumor effect. The elemene liposome drug delivery system is mainly combined with radiotherapy and chemotherapy to treat a variety of malignant tumors. The EE drug delivery system is mainly used for the treatment of digestive tract tumors and can be used as a preventive medication for postoperative recurrence and metastasis. It can improve symptoms such as swallowing obstruction, eating difficulties, and pain caused by digestive tract tumors and can also be used to inhibit various precancerous lesions. $\mathrm{EE}$ is convenient for oral administration compared to liposomes, and it is more convenient to carry and use by solid self-microemulsification. In general, the two drug delivery systems have greatly improved the solubility in water and bioavailability, but how to target the drug to the tumor organs to increase the anticancer effect needs further research.

The study of long-circulating liposomes further enhances the in vivo cycle time of elemene, but the ABC phenomenon still exists, and the liposomes do not release the drug well after reaching the tumor site. It is important to develop an active, tumor-targeting preparation of elemene long-circulating liposomes to achieve precise individualized treatment. Tumor-targeted therapy is mainly divided into passively targeting tumor cells and actively targeting tumor 
cells. Passive targeting enables targeting of tumors via the enhanced permeability and retention (EPR) effect through formulations, such as elemene liposomes, long-circulating liposomes, multidrug-loaded liposomes, as well as elemene oral emulsion, microemulsion, and SEDDS. Active targeting to tumor cells is achieved by the conjugation of ligands, such as monoclonal antibodies, proteins, peptides, carbohydrates, and glycoproteins, to the liposome surface for drug delivery to cells expressing the target surface receptor (Figure 3). For example, in triple-negative breast cancer (TNBC), a number of potential molecular targets that are being studied for the development of targeted therapies for TNBC based on their overexpression among breast cancer subtypes, such as urokinase plasminogen activator receptor (uPAR), EGF receptor (EGFR), IGF-1 receptor, Wnt receptor, MUC1, and folate receptor. The targeting liposomes could extravasate and migrate through the tumor stroma to reach tumor cells by passive targeting (or the EPR effect). Based on the expression of the aforementioned cellular receptors, liposomes that are functionalized with corresponding ligands to specific cell surface targets more effectively mediate intracellular drug delivery via receptor-mediated endocytosis. It is likely that active targeting strategies could deliver large doses of antitumor drugs into cancer cells to maximize therapeutic effects while reducing systemic toxicity ${ }^{68}$ At present, the active targeted preparations of elemene are only folate receptor-mediated liposomes and microemulsions, and the effect is not greatly improved compared to long-circulating liposomes. Recently, peptide-mediated targeting agents have been widely studied in the laboratory and applied to chemotherapeutic drugs, such as fibroblast growth factor receptor (FGFR)-mediated long-circulating liposomes for paclitaxel (PTX), liposomes encapsulating doxorubicin (Dox) conjugated to herpes virus-derived gH625 peptide, and ${ }^{\mathrm{D}} \mathrm{CDX} /$ c(RGDy K)-LS/Dox and iWnt-ATF ${ }_{24}$-IONP-Dox, which enhance the uptake of drug by tumor cells. ${ }^{69-71}$ Peptides with high binding affinities to receptors that are overexpressed in cancer cells are useful because of their simple structure, low immunogenicity, and easy, cost-effective chemical synthesis. Therefore, peptide-modified elemene nanoparticle liposomes may be a potential research field.

Combination chemotherapy regimens containing two or more antitumor drugs have been applied for decades in clinical practice to treat various tumors. Nevertheless, combination therapies are often met with higher toxicity, and different drugs may not reach the same tumor cells to achieve the optimal synergistic effects. The inherent differences in physicochemical and pharmacokinetic properties among drug components also prevent anticancer drugs from being delivered to the right tissue at the right time. The co-delivery of multiple anticancer agents using a nanocarrier may overcome some of these difficulties. Many combinatorial nanoparticle
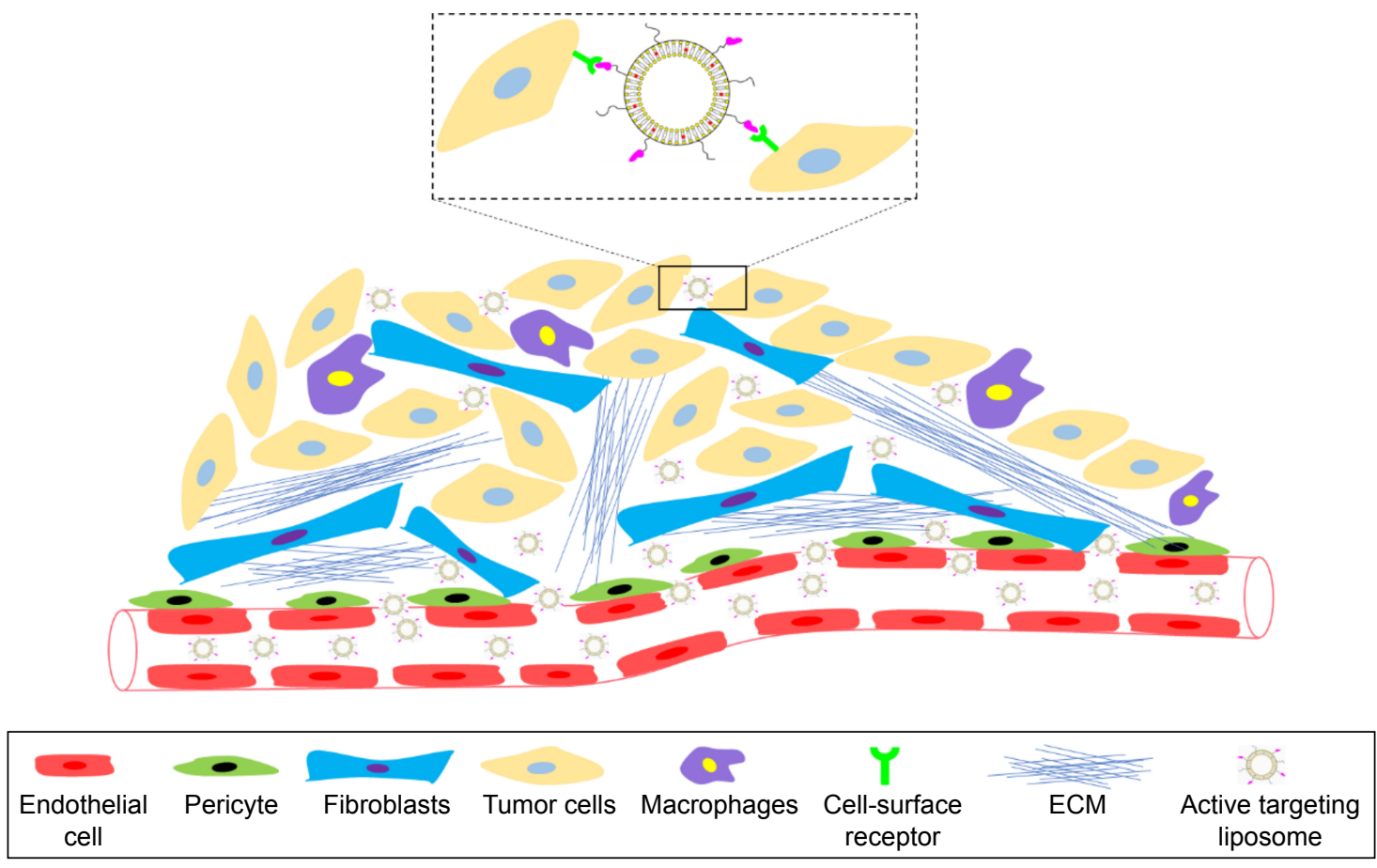

Figure 3 Targeting tumor cells using ligand-directed liposomes. Abbreviation: ECM, extracellular matrix. 
formulations have been successful in promoting the synergistic action by co-delivering combinations of chemotherapy drugs. For instance, CPX-1 liposomes, a 1:1 irinotecan and floxuridine formulation for colorectal cancer treatment, and CPX-351 liposomes, a 5:1 cytarabine and daunorubicin formulation for acute leukemia treatment, could significantly improve patient survival and reduce adverse effects in clinical trials. $^{72-76}$ In the MDA-MB-468 cell line, a novel polymeric nanoparticle system for sequential delivery of erlotinib and Dox successfully enhanced therapeutic efficacy in vitro. ${ }^{77}$ Additionally, there have been reports of coencapsulation of antitumor drug and chemosensitizer, resulting in enhanced MDR reversal, by the simultaneous delivery approach. For example, the co-delivery of vincristine and verapamil in Poly D, L-lactide-co-glycolic acid (PLGA) nanoparticles, coencapsulation of Dox and mitomycin $\mathrm{C}$ in stealth polymerlipid hybrid nanoparticles, and coencapsulation of resveratrol and PTX in PEGylated liposomes all improved the treatment of drug-resistant tumors. ${ }^{61,78,79}$ Yang et $\mathrm{al}^{80}$ even developed an active targeting antibody fragment (AF)-conjugated gemcitabine (GEM) and PTX-loaded liposome (AF-GPL) and further enhanced the therapeutic efficacy in pancreatic cancer treatment. Elemene can enhance the anticancer effects of various chemotherapeutics, such as Dox, cisplatin, and taxanes, and reduce side effects, reversing the drug resistance of chemotherapeutics. For instance, $\beta$-elemene $(50 \mathrm{mg} / \mathrm{kg})$ could compensate for TMZ ( $5 \mathrm{mg} / \mathrm{kg}$ ) to kill both glioma stem-like cells (GSLCs) and non-stem-like cancer cells, probably improving the prognosis of glioma patients tremendously. ${ }^{27} \beta$-elemene $(45 \mathrm{mg} / \mathrm{kg}$ ) also enhanced the antitumor effects of cisplatin $(5 \mathrm{mg} / \mathrm{kg})$ in a gingival squamous cell carcinoma xenograft model by inhibiting the STAT3 signaling pathway..$^{30} \beta$-elemene significantly increased the intracellular accumulation of Dox in both K562/DNR and SGC7901/ADR cells and inhibited the expression of P-gp. Importantly, the combination of Dox $(2 \mathrm{mg} / \mathrm{kg})$ and $\beta$-elemene $(25 \mathrm{mg} / \mathrm{kg})$ drastically inhibited the growth of SGC7901/ADR xenografts in nude mice (tumor weight $1.92 \pm 0.26 \mathrm{~g}, 1.79 \pm 0.37 \mathrm{~g}$, $1.83 \pm 0.53 \mathrm{~g}$, and $0.82 \pm 0.22 \mathrm{~g}$ for saline, Dox, $\beta$-elemene, and combination groups, respectively). ${ }^{81}$ Furthermore, $\beta$-elemene $(100 \mu \mathrm{M})$ sensitized HEK293/ABCB1 cells to PTX by blocking its efflux and increased the sensitivity of the BCRP-overexpressing cell line, NCI-H460/MX20, to mitoxantrone. ${ }^{82}$ In clinical research, Wang et $\mathrm{al}^{83}$ found that elemene-based combinations may increase treatment effectiveness by improving survival and reducing the toxicity of chemotherapy for lung cancer, especially for non-small-cell lung carcinoma (NSCLC), and significantly fewer number of cases of leukocytopenia occurred in the combination group than in the chemotherapy-alone group. ${ }^{83}$ Therefore, coencapsulating $\beta$-elemene and chemotherapy drugs in the same liposome will markedly improve antitumor effect, reduce normal tissue toxicity, and reverse MDR to some extent. If multidrug-loaded liposomes can actively target tumor cells, the therapeutic efficacy will be further increased. The multidrug-loaded liposome is also a potential research direction for $\beta$-elemene. The drug delivery systems of elemene liposome and oral emulsion are summarized in Table 3 and Figure 4.

\section{Safety}

Elemene injection was approved by the CFDA on September 30, 2011, and is in a Phase IV clinical drug adverse reaction monitoring period. It is usually administered by iv injection at a dosage of 400-600 mg once per day, diluted with $0.9 \%$ sodium chloride injection or $5 \%$ glucose injection. For malignant pleural and ascitic fluid, it is generally used at a dose of $200-400 \mathrm{mg} / \mathrm{m}^{2}$ and injected into the chest cavity or abdominal cavity. Compared with chemotherapeutic drugs, $\beta$-elemene has fewer side effects and no obvious heart, liver, and kidney damage. It also rarely causes bone marrow suppression. The median lethal dose $\left(\mathrm{LD}_{50}\right)$ is $270.07 \pm 18.93 \mathrm{mg} / \mathrm{kg}$ by iv injection, and the $\mathrm{LD}_{50}$ is $>5 \mathrm{~g} / \mathrm{kg}$ by oral administration. However, some symptoms may occur on oral or IV administration, including phlebitis, fever, pain, allergy, bleeding, nausea, vomiting, leukocytopenia, baldness, and liver dysfunction (Table 4). ${ }^{83}$ Phlebitis is the most common adverse reaction. The occurrence of phlebitis is mainly related to the irritation, concentration of drug, and the selection of veins. Fever is the second serious adverse reaction. Most patients with relatively strong immunity have temperatures below $38^{\circ} \mathrm{C}$, and patients with very low immunity have temperatures above $39^{\circ} \mathrm{C}$. Fever may be caused by the use of drugs, phlebitis, and the patient's physical condition. Elemene injection can be used for the adjuvant treatment of cancerous pleural effusion and ascites. However, some patients may develop acute chest and abdominal pain after thoracic and intraperitoneal injection due to the strong irritability. Allergic reactions also appear after administration. The main manifestations are chest tightness, shortness of breath, difficulty in breathing, flushing of the neck and face, and sweating. On the one hand, the allergies are related to the patient's specific physique. On the other hand, it may be associated with vasodilatation caused by the vascular irritation due to elemene injection. Some patients also suffer from loss of appetite, nausea, vomiting, and diarrhea after administration. ${ }^{84,85}$

Elemenes are a group of anticancer active ingredients extracted from the volatile oil of $C$. wenyujin 
Table 3 The drug delivery systems of elemene liposome and oral emulsion

\begin{tabular}{|c|c|c|c|c|}
\hline $\begin{array}{l}\text { Drug delivery } \\
\text { system }\end{array}$ & Method & Prescription & Characterization & Ref \\
\hline SLN & $\begin{array}{l}\text { Combining the } \\
\text { techniques of probe } \\
\text { sonication and } \\
\text { membrane extrusion }\end{array}$ & $\begin{array}{l}350 \mathrm{mg} \text { Precirol ATO, I } 50 \text { mg glyceryl } \\
\text { monostearate, } 250 \mathrm{mg} \text { Lutrol F68, } \\
10 \mathrm{~mL} \text { distilled water }\end{array}$ & $\begin{array}{l}\text { Mean size: } 48.9 \pm 2.6 \mathrm{~nm} \text {, zeta } \\
\text { potential: }-30.7 \pm 4.5 \mathrm{mV}, \beta \text {-elemene } \\
\text { concentration: } 5.6 \pm 0.2 \mathrm{mg} / \mathrm{mL} \text {, and } \\
\text { entrapment efficiency: } 99.7 \% \pm 2.5 \%\end{array}$ & 44 \\
\hline NLC & $\begin{array}{l}\text { Hot-melting } \\
\text { high-pressure } \\
\text { homogenization } \\
\text { method }\end{array}$ & $\begin{array}{l}6 \% \text { lipids (glycerol monostearate, a } \\
\text { mixture of Maisine } 35-1 \text { and Labrafil } \\
\text { MI944 CS [I:I]), } 5 \% \text { surfactants } \\
\text { (a mixture of Tween } 80 \text { and soybean } \\
\text { lecithin [I:I]), S/L ratio: } 2: 3 \text {, D/L ratio: I:10 }\end{array}$ & $\begin{array}{l}\text { Mean size: I } 39.8 \mathrm{~nm} \text {, polydispersity } \\
\text { index: } 0.085 \text {, zeta potential: }-20.2 \mathrm{mV} \text {, } \\
\text { drug loading: } 8.45 \% \pm 0.57 \% \text {, and } \\
\text { entrapment efficiency: } 82.11 \% \pm 1.84 \%\end{array}$ & 46 \\
\hline $\begin{array}{l}\text { Sterical-stabilized } \\
\text { liposome }\end{array}$ & $\begin{array}{l}\text { Ethyl ether injection } \\
\text { method }\end{array}$ & $\begin{array}{l}100 \mathrm{mg} \text { phospholipid, } 10 \mathrm{mg} \text { cholesterol, } \\
10 \mathrm{mg} \text { DSPE-PEG } 2000 \text {, and } 50 \mathrm{mg} \\
\beta \text {-elemene }\end{array}$ & $\begin{array}{l}\text { Mean size: } 110 \mathrm{~nm}, \mathrm{pH}: 6.4-6.7 \text {, } \\
\text { content: } 10 \mathrm{mg} / \mathrm{mL} \text {, and entrapment } \\
\text { efficiency: } 97 \%\end{array}$ & 56 \\
\hline $\begin{array}{l}\text { Long-circulating } \\
\text { liposome }\end{array}$ & $\begin{array}{l}\text { Ethanol injection } \\
\text { method }\end{array}$ & $\begin{array}{l}\text { Phospholipid/cholesterol ratio: 5: I, } 50 \mathrm{mg} \\
\beta \text {-elemene, and } 0.05 \% \text { PEG2000 }\end{array}$ & $\begin{array}{l}\text { Mean size: } 221.4 \mathrm{~nm} \text { and entrapment } \\
\text { efficiency: } 92.7 \%\end{array}$ & 57 \\
\hline PLE & $\begin{array}{l}\text { Ethanol injection } \\
\text { method }\end{array}$ & $\begin{array}{l}\text { Phospholipid/cholesterol/DSPE-PEG2000 } \\
\text { ratio: 3:1:0.2 }\end{array}$ & $\begin{array}{l}\text { Mean size: } 149 \mathrm{~nm} \text {, entrapment } \\
\text { efficiency: } 95.2 \% \text {, and concentration of } \\
\beta \text {-elemene: } 5 \mathrm{mg} / \mathrm{mL}\end{array}$ & 47 \\
\hline TLLE & \begin{tabular}{|l|} 
Film dispersion \\
method
\end{tabular} & DPPC/DSPC/DSPE-PEG2000 ratio: 9:1:0.6 & $\begin{array}{l}\text { Mean size: } 103 \mathrm{~nm} \text { and entrapment } \\
\text { efficiency: } 87.9 \%\end{array}$ & 47 \\
\hline FA-PEG-SLN & $\begin{array}{l}\text { Combining the } \\
\text { techniques of probe } \\
\text { sonication and } \\
\text { membrane extrusion }\end{array}$ & $\begin{array}{l}350 \text { mg Precirol ATO, I50 mg glyceryl } \\
\text { monostearate, } 250 \mathrm{mg} \text { Lutrol F68, } \\
0.1 \% \text { FA-PEG-S, } 4 \% \text { CHS-PEG, and } 10 \mathrm{~mL} \\
\text { distilled water }\end{array}$ & $\begin{array}{l}\text { Mean size: } 42.2 \pm 2.1 \mathrm{~nm} \text {, zeta } \\
\text { potential: }-12.60 \pm 1.3 \mathrm{mV} \text {, entrapment } \\
\text { efficiency: } 97.5 \% \pm 1.7 \% \text {, and } \beta \text {-elemene } \\
\text { concentration: } 5.6 \mathrm{mg} / \mathrm{mL}\end{array}$ & 45 \\
\hline $\begin{array}{l}\text { Multidrug-loaded } \\
\text { liposome }\end{array}$ & $\begin{array}{l}\text { Film dispersion } \\
\text { method }\end{array}$ & $\begin{array}{l}20 \mathrm{mg} \text { curcumin, } 5 \mathrm{mg} \beta \text {-elemene, } \\
666.7 \mathrm{mg} \text { lecithin, and I } 33.3 \mathrm{mg} \\
\text { cholesterol }\end{array}$ & $\begin{array}{l}\text { Mean size: } 232.0 \pm 6.4 \mathrm{~nm} \text {, zeta potential: } \\
0.7 \mathrm{I} \pm 0 . \mathrm{I} \mathrm{mV} \text {, encapsulation efficiency } \\
\text { of } \beta \text {-elemene: } 97.86 \% \pm 1.53 \% \text {, } \\
\text { entrapment efficiency of curcumin: } \\
97.71 \% \pm 1.53 \% \text {, and total drug loading: } \\
0.1925 \% \pm 0.006 \%\end{array}$ & 62 \\
\hline $\mathrm{O} / \mathrm{W}$ microemulsion & $\begin{array}{l}\text { Ultrasonication } \\
\text { method in an } \\
\text { ultrasonic bath }\end{array}$ & $\begin{array}{l}\text { I\% Elemene, } 5 \% \text { polysorbate } 80 \text { and } 5 \% \\
\text { ethanol, I5\% propylene glycol, and I5\% } \\
\text { glycerol }\end{array}$ & $\begin{array}{l}\text { Mean size: } 57.7 \pm 2.8 \mathrm{~nm} \text {, polydispersity } \\
\text { index: } 0.485 \pm 0.032 \text {, zeta potential: } \\
3.2 \pm 0.4 \mathrm{mV}, \mathrm{pH}: 5.19 \pm 0.08 \text {, viscosity: } \\
6 \mathrm{mPa} \cdot \mathrm{s}, \text { surface tension: } \\
31.8 \pm 0.3 \mathrm{mN} / \mathrm{m} \text {, elemene content: } \\
8.273 \pm 0.018 \mathrm{mg} / \mathrm{mL} \text {, and entrapment } \\
\text { efficiency: } 99.81 \% \pm 0.24 \%\end{array}$ & 48 \\
\hline Microemulsion & $\begin{array}{l}\text { Water titration } \\
\text { method }\end{array}$ & $\begin{array}{l}\text { I\% Elemene, } 7 \% \text { Labrafac CC, } \\
8 \% \text { phosphatidylcholine, } 8 \% \mathrm{HS}-15 \text {, } \\
16 \% \text { propylene glycol, and } 60 \% \mathrm{PBS} \\
\text { solution (pH 7.4) containing } 0.5 \% \mathrm{NaHSO}_{3}\end{array}$ & $\begin{array}{l}\mathrm{pH}: 7.32 \pm 0.0 \mathrm{I} \text {, osmotic pressure: } \\
279 \pm 3 \mathrm{mosm} / \mathrm{kg} \text {, viscosity: } \\
(5.56 \pm 0.1 \mathrm{I}) \times 10^{-3} \text {, conductivity: } \\
\mathrm{I} .14 \times 10^{-2} \pm 7.9 \times 10^{-5} \mathrm{~s} / \mathrm{m} \text {, refractive } \\
\text { index: } 1.458 \pm 0.004 \text {, zeta potential: } \\
-2.64 \pm 0.06 \mathrm{mV} \text {, and mean size: } 38.3 \pm 4.3 \mathrm{~nm}\end{array}$ & 65 \\
\hline SEDDS soft capsule & NA & $\begin{array}{l}\beta \text {-elemene/ethyl oleate/Tween } 85 / \\
\text { Transcutol ratio: 55:45:60:40 (mass value) }\end{array}$ & $\begin{array}{l}\text { Mean size: } 320 \mathrm{~nm} \text { and zeta } \\
\text { potential: }-3 \mathrm{mV}\end{array}$ & 67 \\
\hline S-SMEDDS & NA & $\begin{array}{l}\beta \text {-elemene/EL-35/LAS/total saponins of } \\
\text { honey locust ratio: } 3: 2: 2: 3\end{array}$ & Mean size: $158 \mathrm{~nm}$ & 49 \\
\hline FRT microemulsion & NA & $\begin{array}{l}\text { I\% Elemene, } 7 \% \text { Labrafac CC, } 8 \% \\
\text { phosphatidylcholine, FA-PEG2000-DOPE } \\
\text { and phospholipid molar ratio of I\%-2\%, } \\
8 \% \mathrm{HS}-15,16 \% \text { propylene glycol, and } \\
58 \%-59 \% \text { PBS solution (pH 7.4) } \\
\text { containing } 0.5 \% \mathrm{NaHSO}_{3}\end{array}$ & $\begin{array}{l}\text { Mean size: } 42.5 \pm 6.3 \mathrm{~nm} \text {, zeta potential: } \\
-2.78 \pm 0.920 \mathrm{mV} \text {, surface tension: } \\
29.9 \mathrm{mN} / \mathrm{m} \text {, and } \mathrm{pH}: 7.30 \pm 0.01\end{array}$ & 50 \\
\hline
\end{tabular}

Notes: $S / L$ ratio: the weight ratio of the solid lipid to liquid lipid (S/L, weight/weight [w:w]); $D / L$ ratio: the weight ratio of the drug to the total lipids (D/L, w/w). Abbreviations: CHS-PEG, monomethoxy polyethylene glycol (2000) succinyl cholesterol; DOPE, I,2-oil acyl phosphatidylethanolamine; DPPC, dipalmitoyl phosphatidyl choline; DSPC, distearoyl phosphatidyl choline; DSPE-PEG2000, distearoyl phosphatidyl ethanolamine-poly(ethylene glycol) 2000; EL-35, Cremophor EL 35; FA-PEG-S, $N$-stearyl-N' -pteroylglutamyl-polyethylene glycol (3350) bis-amine; FA-PEG-SLN, $\beta$-elemene SLN modified with 0.1\% FA-PEG-S and $4 \%$ CHS-PEG; FRT microemulsion, folate receptor-targeted microemulsion; HS, polyoxyethylene esters of PEG-(660)-I2-hydroxyl; LAS, Labrasol; NLC, nanostructured lipid carriers; O/W, oil-in-water; PLE, PEGylated liposome containing $\beta$-elemene; Ref, reference; SEDDS, self-emulsion drug delivery system; SLN, solid lipid nanoparticle; S-SMEDDS, solid self-microemulsion drug delivery system; TLLE, thermosensitive long-circulating liposome containing $\beta$-elemene; NA, not applicable. 

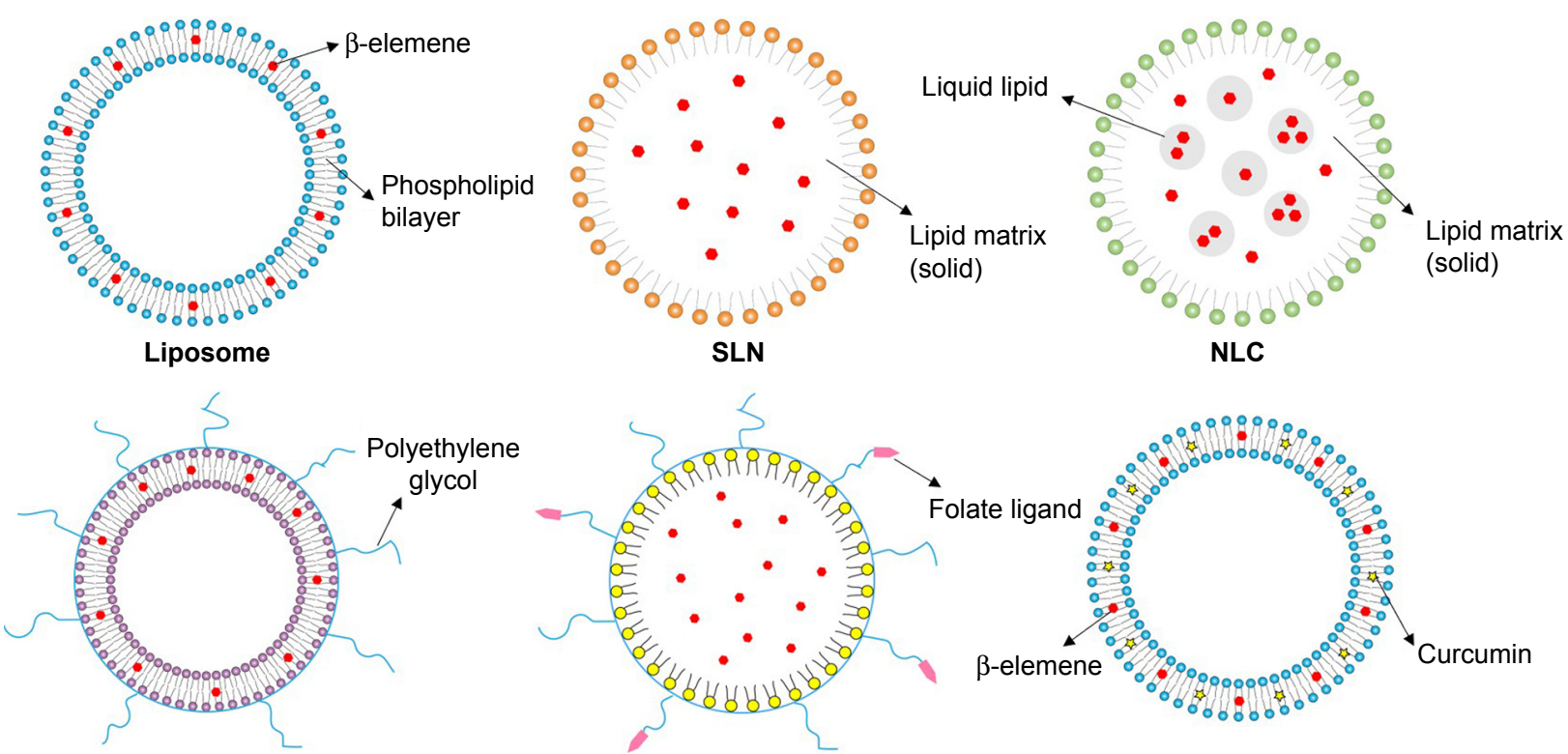

Long-circulating liposome

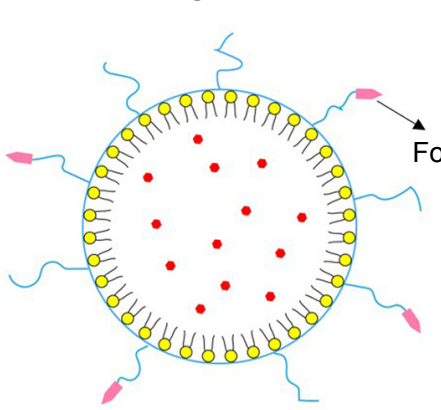

Folate receptortargeting SLN

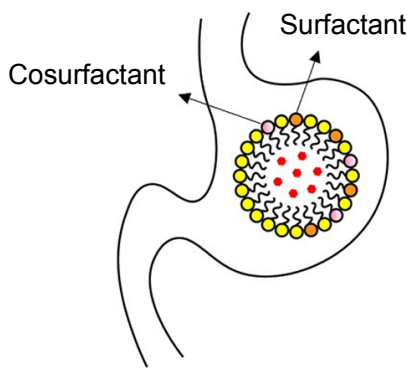

SEDDS

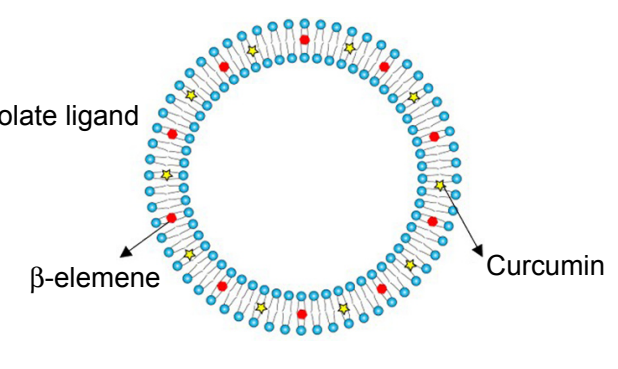

Compound

liposome

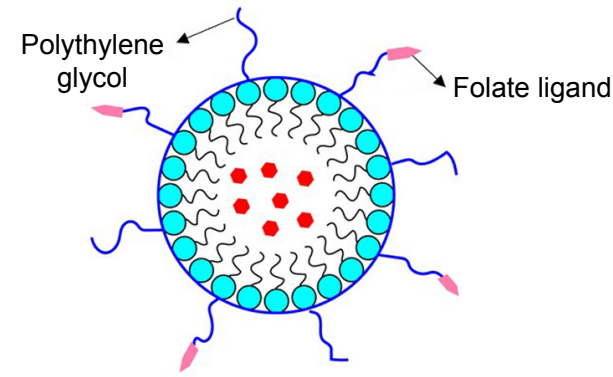

Folate receptortargeting microemulsion

Figure 4 The drug delivery systems of elemene.

Abbreviations: NLC, nanostructured lipid carrier; O/W, oil-in-water; SEDDS, self-emulsion drug delivery system; SLN, solid lipid nanoparticle.

Y. H. Chen et C. Ling. Its main component is $\beta$-elemene, and it also contains a small amount of $\alpha$ - and $\delta$-elemenes and other terpenoids. The occurrence of adverse reactions may be related to the production process and impurity content. The production process must strictly ensure the quality of drugs, remove

Table 4 The main adverse reactions of elemene injection and oral emulsion, as well as the relevant precautions, in the clinic

\begin{tabular}{|l|l|}
\hline Adverse reactions & Precautions \\
\hline Phlebitis & $\begin{array}{l}\text { PICC, } 5 \mathrm{mg} \text { of dexamethasone, flushing } \\
\text { channels with saline, and use of } 50 \% \\
\text { magnesium sulfate solution }\end{array}$ \\
\hline Fever & $\begin{array}{l}\text { Prednisone or indomethacin taken before } \\
\text { administration }\end{array}$ \\
\hline Local pain & $1 \%$ procaine or $2 \%$ lidocaine \\
\hline Allergic reactions & $\begin{array}{l}5-10 \text { mg dexamethasone, oxygen, } \\
\text { promethazine, bronchodilating drugs }\end{array}$ \\
\hline Gastrointestinal reaction & NA \\
\hline Bleeding & NA \\
\hline
\end{tabular}

Abbreviations: NA, not applicable; PICC, peripherally inserted central catheter. sensitizing ingredients as much as possible, and increase the purity of the injection. Elemene injection has a blood circulation effect; thus, it should be used cautiously in patients with thrombocytopenia or bleeding tendency. Selecting deep veins (subclavian vein or internal jugular vein), using a central venous catheter (PICC), and simultaneously administering $5 \mathrm{mg}$ of dexamethasone, as well as flushing channels with saline quickly after using, can prevent phlebitis. Patients with phlebitis can be treated with $50 \%$ magnesium sulfate solution. To prevent or reduce fever, prednisone or indomethacin can be taken orally 30 minutes before administration. For patients with severe pain, $1 \%$ procaine or $2 \%$ lidocaine can effectively relieve pain by iv injection. To prevent the development of allergic asthma or shock, it is recommended that clinical use of the elemene injection should be accompanied by the preventive use of antiallergy drugs. Once an allergic reaction occurs, 5-10 mg of dexamethasone is administered by iv injection, promethazine is intramuscularly administered, oxygen 
is absorbed, and bronchodilating drugs are used. It should be noted that most adverse reactions of elemene injection occurred within 30 minutes after administration. For patients who have used elemene injection for the first time, the drip rate should be set to $20 \mathrm{drops} / \mathrm{min}$. If no adverse reactions occur within 30 minutes, the drip rate should be adjusted to $30-40$ drops/ min. ${ }^{86,87}$ As a low-toxicity, safe, and effective antitumor drug, $\beta$-elemene also has insuperable disadvantages. $\beta$-elemene could upregulate hypoxia-inducible factor $1 \alpha$ (HIF-1 $\alpha$ ) through ROS and the PI3K/Akt/mTOR pathway, which protects human osteosarcoma cells from undergoing apoptosis. ${ }^{88}$ Moreover, $\beta$-elemene inhibits the PI3K/Akt/mTOR pathway but simultaneously induces protective autophagy and prevents human cancer cells from undergoing apoptosis. ${ }^{89-91}$

\section{$\beta$-elemene derivatives}

As discussed herein, $\beta$-elemene has been demonstrated to have anticancer effects in a variety of malignancies. However, the major setback for its use as an anticancer agent is its poor bioavailability and moderate effect on certain type of tumors. Thus, it is necessary to develop new $\beta$-elemene analogs with enhanced antitumor activity and minimal side effects. For these reasons, a few new $\beta$-elemene derivatives have been developed (Figure 2). The following section will discuss several lead compounds (Table 5).
I la

Chen et $\mathrm{al}^{92}$ synthesized a novel furoxan-based NO-donating $\beta$-elemene hybrid that had improved antitumor activities against SGC-7901, HeLa, and U87 cells. Moreover, $11 \mathrm{a}$ arrested the cell cycle at the G2 phase with increase in percentage from $18.86 \%$ to $47.99 \%$ and induced U87 cell apoptosis by inhibiting PI3K/Akt signaling. Further in vivo studies showed the anticancer activity of $11 \mathrm{a}$ with a tumor inhibitory ratio (TIR) of $64.8 \%$, which was higher than that of $\beta$-elemene (TIR, 49.6\%) at a dose of $60 \mathrm{mg} / \mathrm{kg} .{ }^{92}$

\section{Ili}

IIi, 13,14-bis(cis-3,5-dimethyl-1-piperazinyl)- $\beta$-elemene, is a novel $\beta$-elemene derivative with a cis-2,6-dimethylpiperazine substitution and is a potent agent for inhibiting the proliferation of 15 human tumor cell lines, with an average $\mathrm{IC}_{50}$ of $3.44 \mu \mathrm{M}$, and the secondary amino group may contribute to this effect. Ili also exhibited strong cytotoxicity in two MDR cell lines (K562/A02 and MCF-7/Adr), with an average resistance factor $(\mathrm{RF})$ of 1.66. Moreover, IIi reduced tumor growth by $26.0 \%$ and $50.4 \%$ at a dose of 20 and $40 \mathrm{mg} / \mathrm{kg}$ for 7 days, respectively. Mechanistically, treatment with IIi inhibited the mTOR activity and decreased levels of phosphorylated p70S6K1 and 4EBP $1 .{ }^{93}$

Table $5 \beta$-elemene derivatives with antitumor activities

\begin{tabular}{|c|c|c|c|c|}
\hline $\begin{array}{l}\text { Derivatives and } \\
\text { concentrations } \\
\text { used for treatment }\end{array}$ & Cancer cell lines & Major mechanisms & Effects & Ref \\
\hline I la $(0.5-2.0 \mathrm{nM})$ & $\begin{array}{l}\text { Human glioblastoma } \\
\text { U87 cells }\end{array}$ & $\begin{array}{l}\text { Bcl-2 } \downarrow \text { Bax } \uparrow \text { Procaspase- } 3 \downarrow \text { Caspase-3 } \uparrow \\
\text { P-AKT } \downarrow \text { PI3K/Akt } \downarrow\end{array}$ & $\begin{array}{l}\text { G2 phase arrest, } \\
\text { induction of apoptosis }\end{array}$ & 92 \\
\hline Ili (I and $2 \mu \mathrm{M})$ & $\begin{array}{l}\text { Human breast cancer MCF-7 } \\
\text { and MDA-MB- } 468 \text { cells, and } \\
\text { human leukemia } \mathrm{K} 562 \text { cells }\end{array}$ & $\begin{array}{l}\text { Phosphorylated p70S6KI } \downarrow \text { p } 4 \text { EBPI } \downarrow \text { cleaved } \\
\text { LC3 } \uparrow \text { mTOR } \downarrow\end{array}$ & $\begin{array}{l}\text { Inhibition of growth, } \\
\text { induction of autophagy }\end{array}$ & 93 \\
\hline $6 \mathrm{q}(1.0-4.0 \mu \mathrm{M})$ & $\begin{array}{l}\text { Human gastric carcinoma } \\
\text { SGC-790I cells }\end{array}$ & $\begin{array}{l}\text { Cytochrome C (M) } \downarrow \text { Cytochrome C (C) } \uparrow \\
\text { Caspase-3/9 } \uparrow \text { Bcl-2 } \downarrow \text { Bax } \uparrow \text { PARP } \downarrow \\
\text { Cleaved PARP } \uparrow\end{array}$ & $\begin{array}{l}\text { G2 phase arrest, } \\
\text { induction of apoptosis }\end{array}$ & 94 \\
\hline DXI $(6.0-12.0 \mu \mathrm{M})$ & Human leukemia HL-60 cells & $\begin{array}{l}\text { ROS } \uparrow \text { MMP } \downarrow \text { Bid } \downarrow \text { c-FLIP } \downarrow \text { Procaspase-3/8/9 } \downarrow \\
\text { Caspase-8/9 } \uparrow \text { PARP } \downarrow \text { Cleaved PARP } \uparrow\end{array}$ & Induction of apoptosis & 95 \\
\hline $\begin{array}{l}\text { IIm and IIn }(2.0 \text { and } \\
4.0 \mu \mathrm{M})\end{array}$ & Human leukemia $K 562$ cells & $\mathrm{p}-\mathrm{AKT} \downarrow$ p-mTOR $\downarrow$ p-p70S6K $\downarrow$ & Inhibition of growth & 96 \\
\hline ETME $(40 \mu \mathrm{M})$ & $\begin{array}{l}\text { Human leukemia HL- } 60 \\
\text { and NB4 cells }\end{array}$ & $\begin{array}{l}\text { PARP } \downarrow \text { Cleaved PARP } \uparrow \text { Procaspase- } 3 \downarrow \\
\mathrm{H}_{2} \mathrm{O}_{2} \uparrow \text { MMP } \downarrow\end{array}$ & Induction of apoptosis & 97 \\
\hline $\begin{array}{l}\mathrm{ETME}+\mathrm{As}_{2} \mathrm{O}_{3} \\
(20 \mu \mathrm{M}+5 \mu \mathrm{M})\end{array}$ & $\begin{array}{l}\text { Hepatocellular carcinoma } \\
\text { SMMC-772I cells }\end{array}$ & $\begin{array}{l}\text { Procaspase-3/8/9 } \downarrow \text { Bcl-2 } \downarrow \text { MMP } \downarrow \text { Bid } \uparrow \text { Bax } \uparrow \\
\text { p53 } \uparrow \text { Cyclin DI } \uparrow \text { Cyclin BI } \uparrow \text { CDKI } \uparrow \text { p27 } \uparrow\end{array}$ & $\begin{array}{l}\mathrm{G} 2 / \mathrm{M} \text { phase arrest, } \\
\text { induction of apoptosis }\end{array}$ & 98 \\
\hline $4 a, 13$ & $\begin{array}{l}\text { Human cervical } \\
\text { adenocarcinoma HeLa cells }\end{array}$ & Rb phosphorylation $\downarrow$ Cyclin DI $\downarrow$ & GI phase arrest & 100 \\
\hline
\end{tabular}

Notes: $\uparrow$, an increase in target protein; $\downarrow$, a decrease in target protein. $4 \mathrm{a}$, monosubstituted amine derivative of $\beta$-elemene; $6 \mathrm{q}$, $\beta$-elemene isopropanolamine; I la, furoxanbased NO-donating $\beta$-elemene hybrid; I3, Re(CO) ${ }_{3}-\beta$-elemene derivative; Ili, I3, I4-bis(cis-3,5-dimethyl-I-piperazinyl)- $\beta$-elemene; IIm, I 3, I 4-bis[2-(2-thiophenyl)ethylamino]$\beta$-elemene; IIn, I3, I4-bis(cyclohexamino)- $\beta$-elemene; DXI, I3-(3-methyl-I-piperazinyl)- $\beta$-elemene.

Abbreviations: Bcl-2, B-cell lymphoma 2; Bid, binding interface database; ETME, N-( $\beta$-elemene-|3-yl)tryptophan methylester; MMP, mitochondrial membrane potential; Ref, reference. 


\section{$6 q$}

Chen et $\mathrm{al}^{94}$ synthesized a novel $\beta$-elemene isopropanolamine derivative by introducing both amine and hydroxyl groups, which showed stronger cytotoxicity than cisplatin, with $\mathrm{IC}_{50}$ ranging from 4.37 to $10.20 \mu \mathrm{M}$. Moreover, the combination of $6 \mathrm{q}$ with cisplatin showed a synergistic effect, with $\mathrm{IC}_{50}$ ranging from 1.21 to $2.94 \mu \mathrm{M}$, and this combination reversed the MDR of A549/DPP cells, with an $\mathrm{IC}_{50}$ of $2.52 \mu \mathrm{M}$. Mechanically, 6q arrested the cell cycle at the G2 phase and induced SGC-7901 cell apoptosis via mitochondrialdependent signaling. In addition, an in vivo study demonstrated anticancer activity, with a TIR of $60.3 \%$, which was superior to that of $\beta$-elemene (TIR, 49.1\%) at the same dose of $60 \mathrm{mg} / \mathrm{kg} .{ }^{94}$

\section{DXI}

A novel piperazine derivative of $\beta$-elemene with a secondary amino moiety, 13-(3-methyl-1-piperazinyl)- $\beta$-elemene (DX1), was synthesized to inhibit growth of human leukemia HL-60 cells, and it had an average $\mathrm{IC}_{50}$ of $9.2 \mu \mathrm{M}$. DX1 induced cell apoptosis by producing ROS and decreasing mitochondrial membrane potential. In addition, DX1activated caspase-3, -8 and -9 were associated with the downregulation of c-FLIP. In summary, the apoptosis was correlated with the downregulation of c-FLIP and the generation of ROS, which activated the death receptor and mitochondrial-dependent pathways. ${ }^{95}$

\section{$\mathrm{IIm}$ and IIn}

$\mathrm{Xu}$ et $\mathrm{a}^{96}$ synthesized two $\beta$-elemene derivatives containing a thiophenylethylamine or a cyclohexamine, termed 13,14bis[2-(2-thiophenyl)ethylamino]- $\beta$-elemene (IIm) and 13,14bis(cyclohexamino)- $\beta$-elemene (IIn), respectively. IIm and IIn significantly inhibited the growth of K562 cells, with $\mathrm{IC}_{50}$ of 1.3 and $3.7 \mu \mathrm{M}$, respectively, and the secondary amino group might contribute to their inhibitory effect. Mechanically, IIm and IIn inhibited cell growth through mTOR and/or AKT activity. ${ }^{96}$

\section{ETME}

Yu et a $1^{98}$ synthesized the $N$-( $\beta$-elemene-13-yl)tryptophan methyl ester (ETME) using $\beta$-elemene and L-tryptophan methyl ester. ETME inhibited HL-60 and NB4 cell growth and induced apoptosis at concentrations $<40 \mu \mathrm{M}$. The apoptosis was correlated with the generation of $\mathrm{H}_{2} \mathrm{O}_{2}$, the downregulation of MMP, and the activation of caspase-3 (which was blocked by catalase). Furthermore, ETME in combination with arsenic trioxide $\left(\mathrm{As}_{2} \mathrm{O}_{3}\right)$ enhanced inhibition and induced apoptosis through generation of $\mathrm{H}_{2} \mathrm{O}_{2}$, followed by mitochondria-mediated activation of caspase- $3 .{ }^{97}$ In HCC, ETME also exerted potent antiproliferative effects. Moreover, ETME in combination with $\mathrm{As}_{2} \mathrm{O}_{3}$ led to significant apoptosis by increasing the levels of caspase3/8/9, p53, Bax, and Bid and decreasing the MMP and Bcl-2. The combination also induced cell cycle arrest at the $\mathrm{G} 2 / \mathrm{M}$ phase by increasing the cell cycle-related proteins such as p27, cyclin D1, cyclin B1, and CDK1.98

\section{Radioactive conjugate 9}

Sun et al ${ }^{99}$ synthesized the $\beta$-elemene- $-^{99 \mathrm{~m}} \mathrm{Tc}(\mathrm{CO})_{3}\left(\mathrm{H}_{2} \mathrm{O}\right)_{3}{ }^{+}$ conjugate 9 . The oil-water partition coefficient was reported as $P=199.5 \pm 4.12$ and was up to 20 times lower. An in vitro stability study showed that $>90 \%$ of the compound retained its original structure in PBS for 24 hours. Moreover, the kidneys, lung, and liver exhibited the highest uptake in the biodistribution study. However, the complex did not easily permeate the blood-brain barrier, which may be due to the enhanced solubility. Furthermore, it had fast blood clearance ( $>90 \%$ at 24 hours after injection). Micro-single-photon emission computed tomography (SPECT) images indicated that it had a significant accumulation in tumor regions after iv injection..$^{99}$

\section{Other derivatives}

Sun et al ${ }^{100}$ synthesized a $\beta$-elemene monosubstituted amine derivative (4a) and a $\operatorname{Re}(\mathrm{CO})_{3}-\beta$-elemene derivative (13). In vitro antiproliferative activity in HeLa cells was significantly improved through reduction of Rb phosphorylation and cyclin D1 protein level. ${ }^{100} \beta$-elemenal, a synthetic analog of $\beta$-elemene, has been reported to be more potent than $\beta$-elemene in inhibiting H460 and A549 cell growth, with $\mathrm{IC}_{50}$ values at 48 hours of 25.5 and $35.0 \mu \mathrm{g} / \mathrm{mL}$, respectively. ${ }^{8} \mathrm{Lr}-1$ [(R or S)-2-((1R,3S,4S)-3-isopropenyl4-methyl-4-vinyl-cyclohexyl)-propane-1,2-diol] and Lr-2 [(S)-2-((1R,3S,4S)-3-isopropenyl-4-methyl-4-vinylcyclohexyl)-propane-1,2-diol and (R)-2-((1R,3S,4S)-3isopropenyl-4-methyl-4-vinyl-cyclohexyl)-propane-1, 2 -diol], two synthetic analogs of $\beta$-elemene, have the same antitumor efficacy against three brain tumor cell lines, with respective average $\mathrm{IC}_{50}$ values of $102.4 \pm 8.8 \mu \mathrm{g} / \mathrm{mL}(\mathrm{Lr}-1)$ and $100 \pm 30.4 \mu \mathrm{g} / \mathrm{mL}$ (Lr-2) for A172 cells, $73.84 \pm 6.99 \mu \mathrm{g} / \mathrm{mL}$ (Lr-1) and 75.55 $\pm 7.62 \mu \mathrm{g} / \mathrm{mL}$ (Lr-2) for CCF-STTG1 cells, and $80.22 \pm 7.2 \mu \mathrm{g} / \mathrm{mL}$ (Lr-1) and 77.27 $\pm 4.34 \mu \mathrm{g} / \mathrm{mL}(\mathrm{Lr}-2)$ for $\mathrm{U}-87 \mathrm{MG}$ cells and may have great potential as alternatives to $\beta$-elemene for anticancer therapy. ${ }^{101}$ 
In summary, keeping the entire molecular skeleton and double bond of $\beta$-elemene, $\beta$-elemene derivatives were synthesized by introducing nitrogen, oxygen, and sulfur groups at the 13 and 14 positions. $\beta$-elemene derivatives that have been reported mainly include amines, esters, alcohols, amino acids, aldehydes, and radioactive conjugates. The main antitumor mechanism of $\beta$-elemene derivatives is inducing cell apoptosis and arresting the cell cycle. Amine derivatives of $\beta$-elemene are classified into 13-monosubstituted amines and 13,14-disubstituted amine derivatives, which comprise the largest proportion of $\beta$-elemene derivatives and have the highest anticancer activity. The secondary amines, the amine derivatives with active hydrogen attached to nitrogen, such as DX1, IIi, IIm, and IIn, have strong activity. Furoxan subunits can enhance the antitumor activity of $\beta$-elemene by producing high levels of $\mathrm{NO}$ in vitro and inhibiting tumor growth in vivo. The introduction of L-tryptophan methyl ester into $\beta$-elemene evidently increased its antiproliferative activities. ETME in combination with $\mathrm{As}_{2} \mathrm{O}_{3}$ exerts synergistic antitumor effects in human leukemia and hepatocellular carcinoma cells. Radioactive $\beta$-elemene derivatives, such as rheniumcoordinated and technetium-coordinated derivatives, also showed high antitumor activities. $\beta$-elemene derivatives can overcome the shortcomings of $\beta$-elemene in terms of the moderate antitumor activity and poor solubility in water. However, the study of $\beta$-elemene derivatives still has the problem of few structural types, lacking systematic and in-depth study of the antitumor mechanism. More supporting studies are required to discover the optimal $\beta$-elemene derivative with high anticancer activities and no side effects.

\section{Conclusion}

$\beta$-elemene is a noncytotoxic Class II antitumor drug extracted from the traditional Chinese medicine $C$. wenyujin $\mathrm{Y}$. $\mathrm{H}$. Chen et $\mathrm{C}$. Ling. Elemene injection and oral emulsion have been used in the clinic for $>20$ years. Clinicians should pay attention to their adverse reactions, including severe phlebitis, fever, pain, allergy, bleeding, nausea, vomiting, and leukocytopenia, during their application. At present, the drug delivery systems of $\beta$-elemene have only improved the solubility in water and bioavailability, as well as reduced the phlebitis, but have not significantly enhanced the antitumor effect. Some potential $\beta$-elemene derivatives, such as 11a, IIi, 6q, DX1, IIm, IIn, ETME, radioactive conjugate $9,4 \mathrm{a}$, and 13 , have been synthesized and proven to have stronger anticancer activities than $\beta$-elemene. However, the study of $\beta$-elemene derivatives still has the problem of few structural types, lacking systematic and in-depth study of their antitumor mechanism. In the future, active targeting drug delivery systems, especially the peptide-modified elemene nanoparticle liposome, may be a potential research field. Elemene combined with chemotherapy drugs can enhance antitumor effects, reduce side effects, and reverse drug resistance. Multidrug-loaded liposomes also open up a promising option for elemene. More supporting studies, including clinical trials, are required to discover the optimal $\beta$-elemene derivative with high anticancer activities and no side effects.

\section{Acknowledgments}

This work was supported by the Holistic Integrative Pharmacy Institutes, Hangzhou Normal University; Key Laboratory of Elemene Class Anti-cancer Chinese Medicine of Zhejiang Province; Engineering Laboratory of Development and Application of Traditional Chinese Medicine from Zhejiang Province; Key Projects of National Science Foundation of China (81730108); Key Project of Zhejiang project Ministry of Science and Technology (2015C03055); and Key Project of Hangzhou Ministry of Science and Technology (20162013A07, 20142013A63).

\section{Disclosure}

The authors report no conflicts of interest in this work.

\section{References}

1. Tang CY, Zhu LX, Yu JD, et al. Effect of $\beta$-elemene on the kinetics of intracellular transport of d-luciferin potassium salt (ABC substrate) in doxorubicin-resistant breast cancer cells and the associated molecular mechanism. Eur J Pharm Sci. 2018;120:20-29.

2. Jiang Z, Jacob JA, Loganathachetti DS, Nainangu P, Chen B. $\beta$-Elemene: Mechanistic Studies on Cancer Cell Interaction and Its Chemosensitization Effect. Front Pharmacol. 2017;08(27):105.

3. Yu X, Xu M, Li N, et al. $\beta$-elemene inhibits tumor-promoting effect of M2 macrophages in lung cancer. Biochem Biophys Res Commun. 2017; 490(2):514-520.

4. Guo Z, Liu Z, Yue H, Wang J. Beta-elemene increases chemosensitivity to 5-fluorouracil through down-regulating microRNA-191 expression in colorectal carcinoma cells. J Cell Biochem. 2018;119(8):7032-7039.

5. Zhu TZ, Li XM, Luo LH, et al. $\beta$-elemene inhibits stemness, promotes differentiation and impairs chemoresistance to temozolomide in glioblastoma stem-like cells. Int J Oncol. 2014;45(2):699-709.

6. Zhu TZ, Li XM, Luo LH, et al. $\beta$-Elemene inhibits proliferation through crosstalk between glia maturation factor $\beta$ and extracellular signal-regulated kinase $1 / 2$ and impairs drug resistance to temozolomide in glioblastoma cells. Mol Med Rep. 2014;10(2):1122-1128.

7. Li QQ, Lee RX, Liang H, Zhong Y, Reed E. Enhancement of cisplatininduced apoptosis by $\beta$-elemene in resistant human ovarian cancer cells. Med Oncol. 2013;30(1):424.

8. Qq L, Wang G, Huang F, Jm L, Cuff CF, Reed E. Sensitization of lung cancer cells to cisplatin by beta-elemene is mediated through blockade of cell cycle progression: antitumor efficacies of beta-elemene and its synthetic analogs. Med Oncol. 2013;30(1):488.

9. Qq L, Wang G, Liang H, et al. $\beta$-Elemene promotes cisplatin-induced cell death in human bladder cancer and other carcinomas. Anticancer Res. 2013;33(4):1421. 
10. Mu L, Wang T, Chen Y, Tang X, Yuan Y, Zhao Y. $\beta$-Elemene enhances the efficacy of gefitinib on glioblastoma multiforme cells through the inhibition of the EGFR signaling pathway. Int J Oncol. 2016;49(4):1427-1436.

11. Zhang F, Xu L, Qu X, et al. Synergistic antitumor effect of beta-elemene and etoposide is mediated via induction of cell apoptosis and cell cycle arrest in non-small cell lung carcinoma cells. Mol Med Rep. 2011;4(6): 1189-1193.

12. Jiang ZY, Qin SK, Yin XJ, Chen YL, Zhu L. Synergistic effects of Endostar combined with $\beta$-elemene on malignant ascites in a mouse model. Exp Ther Med. 2012;4(2):277-284.

13. Zhou J, He LL, Ding XF, et al. Combinatorial Antitumor Effect of Rapamycin and $\beta$-Elemene in Follicular Thyroid Cancer Cells. Biomed Res Int. 2016;2016(5):6723807.

14. Li X, Lin Z, Zhang B, et al. $\beta$-elemene sensitizes hepatocellular carcinoma cells to oxaliplatin by preventing oxaliplatin-induced degradation of copper transporter 1. Sci Rep. 2016;6(1):21010.

15. Zou B, Li QQ, Zhao J, Li JM, Cuff CF, Reed E. $\beta$-Elemene and taxanes synergistically induce cytotoxicity and inhibit proliferation in ovarian cancer and other tumor cells. Anticancer Res. 2013;33(3):929-940.

16. Li G, Xie B, Li X, et al. Downregulation of peroxiredoxin-1 by $\beta$-elemene enhances the radiosensitivity of lung adenocarcinoma xenografts. Oncol Rep. 2015;33(3):1427-1433.

17. Liu S, Zhou L, Zhao Y, Yuan Y. $\beta$-elemene enhances both radiosensitivity and chemosensitivity of glioblastoma cells through the inhibition of the ATM signaling pathway. Oncol Rep. 2015;34(2):943-951.

18. Wu Z, Wang T, Zhang Y, et al. Anticancer effects of $\beta$-elemene with hyperthermia in lung cancer cells. Exp Ther Med. 2017;13(6):3153-3157.

19. Zhang GN, Ashby CR Jr, Zhang YK, Chen ZS, Guo H. The reversal of antineoplastic drug resistance in cancer cells by $\beta$-elemene. Chin J Cancer. 2015;34(11):488-495.

20. Fang M, Mei X, Yao H, et al. $\beta$-elemene enhances anticancer and antimetastatic effects of osteosarcoma of ligustrazine in vitro and in vivo. Oncol Lett. 2018;15(3):3957-3964.

21. Lee RX, Li QQ, Reed E. $\beta$-Elemene Effectively Suppresses the Growth and Survival of Both Platinum-sensitive and -resistant Ovarian Tumor Cells. Anticancer Res. 2012;32(8):3103-3113.

22. Li CL, Chang L, Guo L, et al. $\beta$-elemene induces caspase-dependent apoptosis in human glioma cells in vitro through the upregulation of Bax and Fas/FasL and downregulation of Bcl-2. Asian Pac J Cancer Prev. 2014;15(23):10407-10412.

23. Li J, JunYu, Liu A, Wang Y. $\beta$-Elemene against human lung cancer via up-regulation of P53 protein expression to promote the release of exosome. Lung Cancer. 2014;86(2):144-150.

24. Liu Y, Jiang ZY, Zhou YL, et al. $\beta$-elemene regulates endoplasmic reticulum stress to induce the apoptosis of NSCLC cells through PERK/ IRE1 $\alpha /$ ATF6 pathway. Biomed Pharmacother. 2017;93:490-497.

25. Wang L, Zhao Y, Wu Q, Guan Y, Wu X. Therapeutic effects of $\beta$-elemene via attenuation of the $\mathrm{Wnt} / \beta$-catenin signaling pathway in cervical cancer cells. Mol Med Rep. 2018;17(3):4299-4306.

26. Zhu T, Li X, Luo L, et al. Reversion of malignant phenotypes of human glioblastoma cells by $\beta$-elemene through $\beta$-catenin-mediated regulation of stemness-, differentiation- and epithelial-to-mesenchymal transitionrelated molecules. J Transl Med. 2015;13(1):356.

27. Feng HB, Wang J, Jiang HR, et al. $\beta$-Elemene Selectively Inhibits the Proliferation of Glioma Stem-Like Cells Through the Downregulation of Notch1. Stem Cells Transl Med. 2017;6(3):830-839.

28. Tong E, Xu Y, Li G, Zou K, Zou L. The effects of $\beta$-elemene on the expression of mTOR, HIF-1 $\alpha$, surviving in lung adenocarcinoma A549 cell. Afr J Tradit Complement Altern Med. 2013;10(4):18-23.

29. Zhao S, Wu J, Zheng F, et al. $\beta$-elemene inhibited expression of DNA methyltransferase 1 through activation of ERK1/2 and AMPK $\alpha$ signalling pathways in human lung cancer cells: the role of Sp1. J Cell Mol Med. 2015;19(3):630-641.

30. Huang C, Yu Y. Synergistic Cytotoxicity of $\beta$-Elemene and Cisplatin in Gingival Squamous Cell Carcinoma by Inhibition of STAT3 Signaling Pathway. Med Sci Monit. 2017;23:1507-1513.
31. Shi H, Liu L, Liu L, Geng J, Zhou Y, Chen L. $\beta$-Elemene inhibits the metastasis of B16F10 melanoma cells by downregulation of the expression of uPA, uPAR, MMP-2, and MMP-9. Melanoma Res. 2014;24(2): 99-107.

32. $\mathrm{Hu} \mathrm{Z}, \mathrm{Wu} \mathrm{H}, \mathrm{Li}$ Y, et al. $\beta$-Elemene inhibits the proliferation of esophageal squamous cell carcinoma by regulating long noncoding RNAmediated inhibition of hTERT expression. Anticancer Drugs. 2015; 26(5):531-539.

33. Zhang J, Zhang H, Chen L, et al. $\beta$-elemene reverses chemoresistance of breast cancer via regulating MDR-related microRNA expression. Cell Physiol Biochem. 2014;34(6):2027-2037.

34. Zhang J, Zhang HD, Yao YF, Zhong SL, Zhao JH, Tang JH. $\beta$-Elemene Reverses Chemoresistance of Breast Cancer Cells by Reducing Resistance Transmission via Exosomes. Cell Physiol Biochem. 2015;36(6): 2274-2286.

35. Chen M, Wang S, Tan M, Wang Y. Applications of nanoparticles in herbal medicine: zedoary turmeric oil and its active compound B-elemene. Am J Chin Med. 2011;39(6):1093-1102.

36. Chang Z, Gao M, Zhang W, Song L, Jia Y, Qin Y. Beta-elemene treatment is associated with improved outcomes of patients with esophageal squamous cell carcinoma. Surg Oncol. 2017;26(4):333-337.

37. Ma C, Zhou W, Yan Z, Qu M, Bu X. $\beta$-Elemene treatment of glioblastoma: a single-center retrospective study. Onco Targets Ther. 2016; 9:7521-7526.

38. Zheng C, Cai X, Wu S, Liu Z, Shi Y, Zhou W. Enhancing effect of betaelemene emulsion on chemotherapy with harringtonine, aclacinomycin, and Ara-c in treatment of refractory/relapsed acute myeloid leukemia. Pak J Med Sci. 2014;30(6):1270-1272.

39. Ly X, Hi D, Zhang MH, Dong JH. The advances in anti-tumor activity and relationship between structure and activity of $\beta$-elemene derivatives. Proceedings of the 13th Chinese Pharmacist Week, Nanning, Guangxi, China, 2 November 2013. Beijing: Chinese Pharmaceutical Association; 2013.

40. Huynh DL, Sharma N, Kumar Singh A, et al. Anti-tumor activity of wogonin, an extract from Scutellaria baicalensis, through regulating different signaling pathways. Chin J Nat Med. 2017;15(1):15-40.

41. Wang K, Li Z, Chen Y, Su C. The pharmacokinetics of a novel antitumor agent, beta-elemene, in Sprague-Dawley rats. Biopharm Drug Dispos. 2005;26(7):301-307.

42. Zhang M, Zhang LY, Dong XZ, Liu P. Spectroscopic studies on binding of beta-elemene to human serum albumin. Zhongguo Zhong Yao Za Zhi. 2014;39(11):2117-2120.

43. Chen Z, Song Y, Che J, et al. Validation of a sensitive gas chromatographicmass spectrometric method for the simultaneous determination of betaelemene and beta-elemenal in human plasma. J Chromatogr B Analyt Technol Biomed Life Sci. 2009;877(4):408-414.

44. Wang Y, Deng Y, Mao S, Jin S, Wang J, Bi D. Characterization and body distribution of beta-elemene solid lipid nanoparticles (SLN). Drug Dev Ind Pharm. 2005;31(8):769-778.

45. Wang YZ. Study on $\beta$-elemene Solid Lipid Nanoparticles [doctoral thesis]. Shenyang: Shenyang Pharmaceutical University; 2005.

46. Shi F, Yang G, Ren J, Guo T, Du Y, Feng N. Formulation design, preparation, and in vitro and in vivo characterizations of $\beta$-Elemeneloaded nanostructured lipid carriers. Int J Nanomedicine. 2013;8: 2533-2541.

47. Wang XM. Studies on $\beta$-elemene Liposome [doctoral thesis]. Shenyang: Shenyang Pharmaceutical University; 2005.

48. Zeng Z, Zhou G, Wang X, et al. Preparation, characterization and relative bioavailability of oral elemene o/w microemulsion. Int J Nanomedicine. 2010;5:567-572.

49. Li ZM. The Preparation Research of Solid SMEDDS for $\beta$-elemene. Shandong: Shandong University of Traditional Chinese Medicine; 2009.

50. Hu CJ. Study on $\beta$-elemene Loaded Active Targeting Microemulsion Drug Delivery System Mediated by Folate Receptor [doctoral thesis]. Shenyang: Shenyang Pharmaceutical University; 2011. 
51. Chen M, Zhang J, Yu S, et al. Anti-Lung-Cancer Activity and Liposome-Based Delivery Systems of $\beta$-Elemene. Evid Based Complement Alternat Med. 2012;2012(4):259523.

52. Xie T, Cl L, Wang SL, Zeng ZW, Wang F, Zhao R. Advances in the research of Elemene Liposome series targeted anticancer natural drugs. Chin J Integr Trad West Med. 2014;34(04):507-512.

53. Tapeinos C, Battaglini M, Ciofani G. Advances in the design of solid lipid nanoparticles and nanostructured lipid carriers for targeting brain diseases. J Control Release. 2017;264:306-332.

54. Garcês A, Amaral MH, Sousa Lobo JM, Silva AC. Formulations based on solid lipid nanoparticles (SLN) and nanostructured lipid carriers (NLC) for cutaneous use: A review. Eur J Pharm Sci. 2018;112: $159-167$.

55. Oude Blenke E, Mastrobattista E, Schiffelers RM. Strategies for triggered drug release from tumor targeted liposomes. Expert Opin Drug Deliv. 2013;10(10):1399-1410.

56. Qi JW. Study on Sterically Stabilized Liposomes of $\beta$-elemene. Zhejiang: Zhejiang University; 2009

57. Li WC. Research on Preparation and Pharmacokinetics for LongCirculating $\beta$-elemene Liposomes. Wuhan: Wuhan University of Technology; 2010.

58. Belfiore L, Saunders DN, Ranson M, Thurecht KJ, Storm G, Vine KL. Towards clinical translation of ligand-functionalized liposomes in targeted cancer therapy: Challenges and opportunities. J Control Release. 2018;277:1-13.

59. Hu CM, Zhang L. Nanoparticle-based combination therapy toward overcoming drug resistance in cancer. Biochem Pharmacol. 2012;83(8): 1104-1111.

60. Zhang RX, Wong HL, Xue HY, Eoh JY, Wu XY. Nanomedicine of synergistic drug combinations for cancer therapy - Strategies and perspectives. J Control Release. 2016;240:489-503.

61. Meng J, Guo F, Xu H, Liang W, Wang C, Yang XD. Combination Therapy using Co-encapsulated Resveratrol and Paclitaxel in Liposomes for Drug Resistance Reversal in Breast Cancer Cells in vivo. Sci Rep. 2016;6(1):22390.

62. Dong BY. Preparation of Compound Liposome of $\beta$-elemene and Curcumin and Study the Anti-Lung Cancer Effect Combined with Docetaxel. Beijing: Beijing University of Chinese Medicine; 2017.

63. Callender SP, Mathews JA, Kobernyk K, Wettig SD. Microemulsion utility in pharmaceuticals: Implications for multi-drug delivery. Int $J$ Pharm. 2017;526(1-2):425-442.

64. Xavier-Junior FH, Vauthier C, Morais ARV, Alencar EN, Egito EST. Microemulsion systems containing bioactive natural oils: an overview on the state of the art. Drug Dev Ind Pharm. 2017;43(5):700-714.

65. Hu CJ, Zhao XL, Li JZ, et al. Preparation and characterization of $\beta$-elemene-loaded microemulsion. Drug Dev Ind Pharm. 2011; 37(7):765-774.

66. Aboulfotouh K, Allam AA, El-Badry M, El-Sayed AM. Role of selfemulsifying drug delivery systems in optimizing the oral delivery of hydrophilic macromolecules and reducing interindividual variability. Colloids Surf B Biointerfaces. 2018;167:82-92.

67. Chen C. The Study on SEDDS Soft Capsules of $\beta$-Elemene. Shenyang: Shenyang Pharmaceutical University; 2006.

68. Miller-Kleinhenz JM, Bozeman EN, Yang L. Targeted nanoparticles for image-guided treatment of triple-negative breast cancer: clinical significance and technological advances. Wiley Interdiscip Rev Nanomed Nanobiotechnol. 2015;7(6):797-816.

69. Perillo E, Porto S, Falanga A, et al. Liposome armed with herpes virus-derived gH625 peptide to overcome doxorubicin resistance in lung adenocarcinoma cell lines. Oncotarget. 2016;7(4):4077-4092.

70. Wei X, Gao J, Zhan C, et al. Liposome-based glioma targeted drug delivery enabled by stable peptide ligands. J Control Release. 2015;218:13-21.

71. Miller-Kleinhenz J, Guo X, Qian W, et al. Dual-targeting Wnt and uPA receptors using peptide conjugated ultra-small nanoparticle drug carriers inhibited cancer stem-cell phenotype in chemo-resistant breast cancer. Biomaterials. 2018;152:47-62.
72. Batist G, Sawyer M, Gabrail N, et al. A multicenter, phase II study of CPX-1 liposome injection in patients (pts) with advanced colorectal cancer (CRC). Clin Oncol. 2008;26(15_suppl):4108.

73. Batist G, Gelmon KA, Chi KN, et al. Safety, pharmacokinetics, and efficacy of CPX-1 liposome injection in patients with advanced solid tumors. Clin Cancer Res. 2009;15(2):692-700.

74. Lim WS, Tardi PG, Dos Santos N, et al. Leukemia-selective uptake and cytotoxicity of CPX-351, a synergistic fixed-ratio cytarabine: daunorubicin formulation, in bone marrow xenografts. Leuk Res. 2010; 34(9):1214-1223.

75. Feldman EJ, Lancet JE, Kolitz JE, et al. First-In-Man Study of CPX-351: A Liposomal Carrier Containing Cytarabine and Daunorubicin in a Fixed 5:1 Molar Ratio for the Treatment of Relapsed and Refractory Acute Myeloid Leukemia. J Clin Oncol. 2011;29(8): 979-985.

76. Brunetti C, Anelli L, Zagaria A, Specchia G, Albano F. CPX-351 in acute myeloid leukemia: can a new formulation maximize the efficacy of old compounds? Expert Rev Hematol. 2017;10(10) :853-862.

77. Zhou Z, Kennell C, Jafari M, et al. Sequential delivery of erlotinib and doxorubicin for enhanced triple negative Breast cancer treatment using polymeric nanoparticle. Int J Pharm. 2017;530(1-2):300-307.

78. Song XR, Cai Z, Zheng Y, et al. Reversion of multidrug resistance by co-encapsulation of vincristine and verapamil in PLGA nanoparticles. Eur J Pharm Sci. 2009;37(3-4):300-305.

79. Prasad P, Shuhendler A, Cai P, Rauth AM, Wu XY. Doxorubicin and mitomycin $\mathrm{C}$ co-loaded polymer-lipid hybrid nanoparticles inhibit growth of sensitive and multidrug resistant human mammary tumor xenografts. Cancer Lett. 2013;334(2):263-273.

80. Yang W, Hu Q, Xu Y, Liu H, Zhong L. Antibody fragment-conjugated gemcitabine and paclitaxel-based liposome for effective therapeutic efficacy in pancreatic cancer. Mater Sci Eng C Mater Biol Appl. 2018;89:328-335.

81. Zhang $\mathrm{Y}, \mathrm{Mu} \mathrm{XD}$, Li EZ, et al. The role of E3 ubiquitin ligase $\mathrm{Cbl}$ proteins in $\beta$-elemene reversing multi-drug resistance of human gastric adenocarcinoma cells. Int J Mol Sci. 2013;14(5):10075-10089.

82. Guo HQ, Zhang GN, Wang YJ, et al. $\beta$-Elemene, a compound derived from Rhizoma zedoariae, reverses multidrug resistance mediated by the ABCB1 transporter. Oncol Rep. 2014;31(2):858-866.

83. Wang B, Peng XX, Sun R, et al. Systematic review of $\beta$-Elemene injection as adjunctive treatment for lung cancer. Chin J Integr Med. 2012;18(11):813-823.

84. Ma J, Chen J, Zhao BJ, Jiang ZY, Feng L, Jia XB. Advance in research on anticancer drug $\beta$-elemene and its derivatives. Chin Tradit and Herbal Drugs. 2018;49(5):1184-1191.

85. Tao XM, Gao WB. The adverse reactions and prevention of elemene emulsion injection. ADRJ. 2003;6:390-392.

86. Wang YJ, Zhang R, Wang W. Adverse reactions caused by intravenous infusion of elemene injection in 6 cases. Chin Hosp Pharm J. 2016; 36(4):337-338.

87. Xu T, Zhong L, Js D. Adverse Drug Reaction Induced by Elemene Injection: Literature Analysis of 37 Cases. Asia-Pac Tradit Med. 2014;10(9):126-128.

88. Liang D, Yang M, Guo B, Yang L, Cao J, Zhang X. HIF-1 $\alpha$ induced by $\beta$-elemene protects human osteosarcoma cells from undergoing apoptosis. J Cancer Res Clin Oncol. 2012;138(11):1865-1877.

89. Zhan YH, Liu J, Qu XJ, et al. $\beta$-Elemene induces apoptosis in human renal-cell carcinoma 786-0 cells through inhibition of MAPK/ERK and PI3K/Akt/mTOR signalling pathways. Asian Pac J Cancer Prev. 2012;13(6):2739-2744.

90. Liu J, Hu XJ, Jin B, Qu XJ, Hou KZ, Liu YP. $\beta$-Elemene induces apoptosis as well as protective autophagy in human non-small-cell lung cancer A549 cells. J Pharm Pharmacol. 2012;64(1):146-153.

91. Liu J, Zhang Y, Qu J, et al. $\beta$-Elemene-induced autophagy protects human gastric cancer cells from undergoing apoptosis. BMC Cancer. 2011;11(1):183. 
92. Chen J, Wang T, Xu S, et al. Discovery of novel antitumor nitric oxidedonating $\beta$-elemene hybrids through inhibiting the PI3K/Akt pathway. Eur J Med Chem. 2017;135:414-423.

93. Ding XF, Shen M, Xu LY, Dong JH, Chen G. 13,14-bis(cis-3,5dimethyl-1-piperazinyl)- $\beta$-elemene, a novel $\beta$-elemene derivative, shows potent antitumor activities via inhibition of mTOR in human breast cancer cells. Oncol Lett. 2013;5(5):1554-1558.

94. Chen J, Wang T, Xu S, et al. Novel hybrids of natural $\beta$-elemene bearing isopropanolamine moieties: Synthesis, enhanced anticancer profile, and improved aqueous solubility. Fitoterapia. 2017;120:117-125.

95. Yu Z, Wang R, Xu L, Xie S, Dong J, Jing Y. $\beta$-Elemene piperazine derivatives induce apoptosis in human leukemia cells through downregulation of c-FLIP and generation of ROS. PLoS One. 2011;6(1): e15843.

96. Xu L, Tao S, Wang X, et al. The synthesis and anti-proliferative effects of beta-elemene derivatives with $\mathrm{mTOR}$ inhibition activity. Bioorg Med Chem. 2006;14(15):5351-5356.

97. Yu Z, Wang R, Xu L, Dong J, Jing Y. N-(beta-Elemene-13-yl)tryptophan methyl ester induces apoptosis in human leukemia cells and synergizes with arsenic trioxide through a hydrogen peroxide dependent pathway. Cancer Lett. 2008;269(1):165-173.
98. Yu Z, Wu F, Chen L, et al. ETME, a novel $\beta$-elemene derivative, synergizes with arsenic trioxide in inducing apoptosis and cell cycle arrest in hepatocarcinoma cells via a p53-dependent pathway. Acta Pharm Sin B. 2014;4(6):424-429.

99. Sun Y, Ren Y, Zhu H, et al. Radioactive synthesis and biodistribution study of beta-elemene-99mTc(CO)3 conjugates. J Biol Inorg Chem. 2009;14(6):899-904.

100. Sun Y, Liu G, Zhang Y, Zhu H, Ren Y, Shen YM. Synthesis and in vitro anti-proliferative activity of beta-elemene monosubstituted derivatives in HeLa cells mediated through arrest of cell cycle at the G1 phase. Bioorg Med Chem. 2009;17(3):1118-1124.

101. Li QQ, Lee RX, Liang H, Zhong Y. Anticancer activity of $\beta$-Elemene and its synthetic analogs in human malignant brain tumor cells. Anticancer Res. 2013;33(1):65-76.
International Journal of Nanomedicine

\section{Publish your work in this journal}

The International Journal of Nanomedicine is an international, peerreviewed journal focusing on the application of nanotechnology in diagnostics, therapeutics, and drug delivery systems throughout the biomedical field. This journal is indexed on PubMed Central, MedLine, CAS, SciSearch ${ }^{\circledR}$, Current Contents ${ }^{\circledR} /$ Clinical Medicine,

\section{Dovepress}

Journal Citation Reports/Science Edition, EMBase, Scopus and the Elsevier Bibliographic databases. The manuscript management system is completely online and includes a very quick and fair peer-review system, which is all easy to use. Visit http://www.dovepress.com/ testimonials.php to read real quotes from published authors. 